\title{
Impact of intraseasonal wind bursts on sea surface temperature variability in the far eastern tropical Atlantic Ocean during boreal spring 2005 and 2006: focus on the mid-May 2005 event
}

\author{
Gaëlle Herbert and Bernard Bourlès \\ Institut de Recherche pour le Développement (IRD), Laboratoire d'Etudes Géophysiques et Océanographie Spatiale \\ (LEGOS), Brest, France
}

Correspondence: Gaëlle Herbert (gaelle.herbert@ird.fr)

Received: 4 September 2017 - Discussion started: 4 October 2017

Revised: 19 June 2018 - Accepted: 11 July 2018 - Published: 27 August 2018

\begin{abstract}
The impact of boreal spring intraseasonal wind bursts on sea surface temperature variability in the eastern tropical Atlantic Ocean in 2005 and 2006 is investigated using numerical simulation and observations. We especially focus on the coastal region east of $5^{\circ} \mathrm{E}$ and between the Equator and $7^{\circ} \mathrm{S}$ that has not been studied in detail so far. For both years, the southerly wind anomalies induced cooling episodes through (i) upwelling processes, (ii) vertical mixing due to the vertical shear of the current, and for some particular events (iii) a decrease in incoming surface shortwave radiation. The strength of the cooling episodes was modulated by subsurface conditions affected by the arrival of Kelvin waves from the west influencing the depth of the thermocline. Once impinging the eastern boundary, the Kelvin waves excited westward-propagating Rossby waves, which combined with the effect of enhanced westward surface currents contributed to the westward extension of the cold water. A particularly strong wind event occurred in mid-May 2005 and caused an anomalous strong cooling off Cape Lopez and in the whole eastern tropical Atlantic Ocean. From the analysis of oceanic and atmospheric conditions during this particular event, it appears that anomalously strong boreal spring wind strengthening associated with anomalously strong Hadley cell activity prematurely triggered the onset of coastal rainfall in the northern Gulf of Guinea, making it the earliest over the 1998-2008 period. No similar atmospheric conditions were observed in May over the 1998-2008 period. It is also found that the anomalous oceanic and atmospheric conditions associated with the event exerted a strong influence on rainfall off northeast Brazil. This study highlights the different processes through which the wind power from the South Atlantic
\end{abstract}

is brought to the ocean in the Gulf of Guinea and emphasizes the need to further document and monitor the South Atlantic region.

\section{Introduction}

The eastern equatorial Atlantic Ocean shows a pronounced seasonal cycle in sea surface temperature (SST) (Wauthy, 1983; Mitchell and Wallace, 1992). One strong signature of the SST seasonal cycle in the eastern equatorial Atlantic is the Atlantic cold tongue (ACT) (Zebiak, 1993) characterized by a fast drop of SST (up to $7^{\circ} \mathrm{C}$ ) in boreal spring and summer slightly south of the Equator and east of $20^{\circ} \mathrm{W}$ (Merle, 1980; Picaut, 1983). During boreal summer, the southern boundary of this cooler temperature connects progressively with the austral winter cooling of the Southern Hemisphere SSTs. A number of observational (Merle, 1980; Foltz et al., 2003) and modeling (Philander and Pacanowski, 1986; Yu et al., 2006; Peter et al., 2006) studies show that the development of the ACT is driven by the seasonal increase in the Southern Hemisphere trade winds during late boreal winter to early summer (Brandt et al., 2011) associated with the meridional displacement of the Intertropical Convergence Zone (ITCZ) (Picaut, 1983; Colin, 1989; Waliser and Gautier, 1993; Nobre and Shukla, 1996). The equatorial cooling is regulated by a coupling between thermocline shoaling, subsurface dynamics (Yu et al., 2006; Peter et al., 2006; Wade et al., 2011; Jouanno et al., 2011), including turbulent mixing, vertical advection, and entrainment, and horizontal 
advection. The equatorial thermocline shoaling is the consequence of local and remote wind forcing: the strengthening of easterly winds in the western equatorial Atlantic remotely forces the seasonal upwelling in the eastern part of the basin via equatorial Kelvin waves (Moore et al., 1978; Adamec and O’Brien, 1978; Busalacchi and Picaut, 1983; McCreary et al., 1984).

Besides the dominant seasonal cycle, the eastern tropical Atlantic is under the influence of meridional southerly winds (Picaut, 1984), which fluctuate with a period close to 15 days (Krishnamurti, 1980; de Coëtlogon et al., 2010; Jouanno et al., 2013). These intraseasonal wind fluctuations are therefore expected to be a major contributor to seasonal SST cooling and occur as an energy and momentum carrier from the South Atlantic to the eastern equatorial Atlantic. A connection between the strength of the St. Helena anticyclone and SST anomalies in the southeastern tropical Atlantic has been described by Lübbecke et al. (2014). These authors suggest that the St. Helena anticyclone variability might be an important source of anomalous tropical Atlantic wind power, which affects SST in the eastern equatorial Atlantic via several mechanisms: zonal wind stress changes in the western equatorial basin, wave adjustment, meridional advection of subsurface temperature anomalies, intraseasonal wind stress variations, and possibly even other mechanisms. Through the in situ data analysis of AMMA-EGEE cruises (Redelsperger et al., 2006; Bourlès et al., 2007) carried out in 2005 and 2006, Marin et al. (2009) show that the SST seasonal cooling at the Equator east of $10^{\circ} \mathrm{W}$ is not smooth but results from the succession of short-duration cooling episodes generated by southeasterly wind bursts due to the fluctuating St. Helena anticyclone. In addition, according to Leduc-Leballeur et al. (2013), the sharp and durable change in the atmospheric circulation in the northern Gulf of Guinea (durably strong southerlies north of the Equator) takes place through an abrupt seasonal transition prepared by a succession of southerly wind bursts and possibly triggered by a significantly stronger wind burst. The southerly wind bursts occurring in boreal spring in the Gulf of Guinea would thus play an important role in driving the precipitation pattern in the area through air-sea interactions (de Coëtlogon et al., 2010; Nicholson and Dezfuli, 2013) and coupling between the ACT and the West African monsoon (WAM).

Improving our understanding of the impact of such wind bursts on SST variability at the intraseasonal scale in the eastern tropical Atlantic is important through its link with the regional climate. However, while the ACT and AngolaBenguela regions have been the subject of many studies, the dynamics and SST variability of the coastal eastern region are much less documented.

In this study, we therefore first focus our analysis on offshore Cape Lopez (defined as $0^{\circ} \mathrm{N}-7^{\circ} \mathrm{S}, 5^{\circ} \mathrm{E}-14^{\circ} \mathrm{E}$ and hereafter called the CLR for "Cape Lopez region"; see Fig. 2) and aim to improve understanding of its seasonal SST variability and the impact of intraseasonal winds on SST variabil- ity during boreal spring and summer. To this end, we use regional high-resolution model results as well as satellite SST data and sea surface height observations. We first use model outputs from 1998 to 2008 to analyze the seasonal cycle in the CLR and to highlight its interannual variability, and then we especially focus on the years 2005 and 2006 to investigate the SST response of intraseasonal wind forcing. These two particular years were largely investigated during the African Monsoon Multidisciplinary Analyses (AMMA) experiment (Redelsperger et al., 2006). The year 2005 is characterized by the lowest SST values in the ACT during the past 3 decades (along with 1982), while 2006 is considered as a normal year (Caniaux et al., 2011). Also, 2005 exhibits the earliest development of the ACT. The study of SST variability at the intraseasonal scale during these two years is thus interesting for better understanding their observed differences in SST seasonal conditions. These two particular years have also been chosen by Marin et al. (2009) to study the variability of the properties of the ACT. Their study concerned the equatorial area west of $4^{\circ} \mathrm{E}$, whereas we propose focusing on the CLR east of $5^{\circ} \mathrm{E}$ where coastal processes are expected to be involved.

The question of the processes implied in the SST variability in the Cape Lopez region was raised based on an observation in satellite SST data of cold coastal waters during boreal spring independent from those observed offshore in the cold tongue region around $10^{\circ} \mathrm{W}$ (see Fig. 2), which also raised the question of the link of such cooling with the cold tongue development. Most studies on the CLR have focused on the analysis of observational datasets to examine the hydrology and its seasonal variation along the frontal (coastal) region of the Congo (e.g., Merle, 1972; Piton, 1988) or on the impact of the Congo River on SST and the mixed layer (e.g., Materia et al., 2012; Denamiel et al., 2013; White and Toumi, 2014). However, to our knowledge, no detailed analysis of SST variability at seasonal and intraseasonal timescales has been realized. A better understanding of ocean-atmosphere interactions in this region is thus needed. Some previous studies related to the whole eastern tropical Atlantic (Gulf of Guinea) suggest that multiple processes could be at play in the CLR, coupling remote and local forcing. For example, Giordani et al. (2013) show from regional model results that horizontal advection, entrainment, and turbulent mixing significantly contribute to the heat budget east of $3^{\circ} \mathrm{W}$ because of the very thin mixed layer. The upper layers of the north CLR might also be impacted by vertical mixing induced by the intense current vertical shear between the South Equatorial Current flowing westward at the surface and the subsurface eastward equatorial undercurrent. In addition to local forcing, the area is also under the influence of the arrival of equatorial Kelvin waves from the west and their reflection, once reaching the African coast, poleward as coastally trapped waves and westward as Rossby waves (Moore, 1968; McCreary, 1976; Moore and Philander, 1977). The principal source of the equatorial Kelvin waves has usually been re- 
lated to the western equatorial zonal wind changes during late boreal winter to early summer (e.g., Philander, 1990). In order to better understand the trigger mechanism of Kelvin wave generation that conditions the mixed layer properties in the CLR, another purpose of this study is thus to identify the atmospheric conditions coinciding with Kelvin wave generation in the west of the basin during winter 2005 and 2006. In addition, some studies (such as de Coëtlogon et al., 2010) suggest that at short timescales (a few days), more than half of the cold SST anomaly around the equatorial cooling could be explained by horizontal oceanic advection of upwelled cold coastal waters controlled by the winds. Therefore, a better understanding of the SST variability in the CLR may also help to better understand the SST variability in the equatorial region.

Several studies (e.g., Okumura and Xie, 2004; Caniaux et al., 2011; Nguyen et al., 2011; Thorncroft et al., 2011) show evidence of a high correlation between the ACT and the WAM onset in the Sahelian region. Based on an analysis of 27 years of data, Caniaux et al. (2011) identified the year 2005 as the year with the earliest WAM onset date (around 19 May 2005; they define the mean onset date on 23 June \pm 8 days). According to Marin et al. (2009), the time shift in the development of the ACT between 2005 and 2006 is related to a particular wind burst event in mid-May 2005. This midMay 2005 event therefore appears as exerting a strong influence on the WAM. In the second part of the study, we thus focus on this particular wind event that preceded a strong cold event in the far eastern tropical Atlantic along with an early ACT development. We aim to describe (i) the atmospheric and oceanic conditions during this particular event, (ii) to what extent it is involved in the WAM system, and (iii) which processes make it an exceptional event.

The remainder of the paper is organized as follows. In Sect. 2, the model and observational data used in this study are described. The seasonal and interannual variability of SST, winds, currents, $20^{\circ} \mathrm{C}$ isotherm depth, and sea surface heat flux in the CLR are analyzed in Sect. 3. The cooling episodes generated in response to southerly wind bursts and the other forcing mechanisms implied in the CLR are investigated in detail for the years 2005 and 2006 in Sect. 4. In Sect. 5, we focus our analysis on the unusual wind burst occurring in mid-May 2005. Finally, the main results are summarized and discussed in Sect. 6.

\section{Model and data}

The numerical model used in this paper is the Regional Oceanic Modeling System (ROMS) (Shchepetkin and McWilliams, 2005). The model configuration is the same as employed in Herbert et al. (2016), and the following text is derived from there with minor modifications.

ROMS is a three-dimensional, free-surface, split-explicit ocean model, which solves the Navier-Stokes primitive equations following the Boussinesq and hydrostatic approximations. We used the ROMS version developed at the Institut de Recherche pour le Développement (IRD) featuring a two-way nesting capability based on AGRIF (adaptive grid refinement in Fortran) (Debreu et al., 2012). The two-way capability allows interactions between a large-scale (parent) configuration at lower resolution and a regional (child) configuration at high resolution. The ROMSTOOLS package (Penven et al., 2008) is used for the design of the configuration. The model configuration is built following that performed by Djakouré et al. (2014) over the tropical Atlantic. The large-scale domain extends from $60^{\circ} \mathrm{W}$ to $15.3^{\circ} \mathrm{E}$ and from $17^{\circ} \mathrm{S}$ to $8^{\circ} \mathrm{N}$, and the nested high-resolution zoom focuses on the domain between $17^{\circ} \mathrm{S}$ and $6.6^{\circ} \mathrm{N}$ and between $10^{\circ} \mathrm{W}$ and $14.1^{\circ} \mathrm{E}$. This configuration allows for equatorial Kelvin waves induced by trade wind variations in the western part of the basin to propagate into the Gulf of Guinea and influence the coastal upwelling (Servain et al., 1982; Picaut, 1983). The horizontal grid resolution is $1 / 5^{\circ}$ (i.e., $22 \mathrm{~km}$ ) for the parent grid and $1 / 15^{\circ}$ (i.e., $7 \mathrm{~km}$ ) for the child grid (see Herbert et al. (2016), their Fig. 1). This allows for an accurate resolution of the mesoscale dynamics since the first baroclinic Rossby radius of deformation ranges from 150 to $230 \mathrm{~km}$ in the region (Chelton et al., 1998). The vertical coordinate is discretized into 45 sigma levels with vertical S-coordinate surface and bottom stretching parameters set respectively to theta_s $=6$ and theta_b $=0$ to keep a sufficient resolution near the surface (Haidvogeland Beckmann, 1999). The vertical S-coordinate Hc parameter, which gives the approximate transition depth between the horizontal surface levels and the bottom terrainfollowing levels, is set to $\mathrm{Hc}=10 \mathrm{~m}$. The GEBCO1 (Global Earth Bathymetric Chart of the Oceans) is used for the topography (www.gebco.net, last access: June 2009). The runoff forcing is provided from Dai and Trenberth's global monthly climatological runoff dataset (Dai and Trenberth, 2002). The river properties of salinity and temperature are prescribed as annual mean values. One river (Amazon) is prescribed in the parent model, while five rivers that correspond to the major rivers around the Gulf of Guinea are prescribed in the child model (Congo, Niger, Ogoou, Sanaga, Volta). At the surface, the model is forced with the surface heat and freshwater fluxes as well as 6-hourly wind stress derived from the Climate Forecast System Reanalysis (CFSR) (horizontal resolution of $\left.1 / 4^{\circ} \times 1 / 4^{\circ}\right)$ (Saha et al., 2010). Our model has three open boundaries (north, south, and west) forced by temperature and salinity fields from the Simple Ocean Data Analyses (SODA) (horizontal resolution of $1 / 2^{\circ} \times 1 / 2^{\circ}$ ) (Carton et al., 2000a, b; Carton and Giese, 2008). The simulation has been performed on the IFREMER Caparmor supercomputer and integrated for 30 years from 1979 to 2008 with the outputs averaged every 2 days. A statistical equilibrium is reached after $\sim 10$ years of spin-up. Model analyses are based on the 2-day averaged model outputs from the years 1998 to 2008 . The model has already been validated suc- 
cessfully with a large set of measurements and climatological data, and more detailed information about the model validations can be found in Herbert et al. (2016).

Note that throughout the text and figure captions, the term "intraseasonal variations" is used to designate the field obtained after removing the 30-day low-pass-filtered field from the total field of the given year, while "intraseasonal anomaly" refers to the field obtained after removing the 30day low-pass-filtered field averaged over 1998-2008 from the total field of the given year.

For SST observations, we use data obtained from measurements made by the Tropical Rainfall Measuring Mission microwave imager (TMI). The dataset is a merged product produced by Remote Sensing Systems and sponsored by the NASA Earth Sciences Program. The data are available at http://www.remss.com/missions/tmi (Wentz et al., 2015). The SST data have a spatial resolution of $1 / 4^{\circ}$ and for the present study the 10-year time series, from 1 January 1998 to 31 December 2008, are obtained as 3-daily fields. The important feature of microwave retrievals is that they can give accurate SST measurements under clouds (Wentz et al., 2000). However, the major limitation of microwave TMI observations is land contamination, which results in biases of the order of $0.6^{\circ} \mathrm{K}$ within about $100 \mathrm{~km}$ from the coast (Gentemann et al., 2010). Thus, in the optimal interpolation TMI product the offshore zone with no data extends to approximately $100 \mathrm{~km}$ from the coast. This limits to some degree the analysis of near-coastal regions, in particular those dominated by coastal upwelling dynamics.

We also use for this study daily sea surface height (SSH) data, which are available for the period 1993-2012 and maintained by the organization for Archiving, Validation, and Interpretation of Satellite Oceanographic data with support from CNES (AVISO, 2017; https://www.aviso.altimetry.fr/en/data/products/ sea-surface-height-products/global/msla-h.html). The sea surface height dataset is a merged product of observations from several satellite missions of Ssalto/Duacs (Segment Sol multimissions d'ALTimétrie, d'Orbitographie et de localisation précise - Developing Use of Altimetry for Climate Studies) mapped onto a $0.25^{\circ}$ Mercator projection grid. All standard corrections have been made to account for atmospheric (wet troposphere, dry troposphere, and ionosphere delays) and oceanographic (electromagnetic bias, ocean, load, solid Earth, and pole tides) effects. The mean sea surface topography for the period 1993-2012 was removed from the SSH to produce sea surface height anomalies.

In addition, surface pressure data were studied using ECMWF Atmospheric Reanalysis (ERA) for the 20th Century product (European Centre for Medium-Range Weather Forecasts, 2014). The 4-hourly data are daily averaged and available at https://doi.org/10.5065/D6VQ30QG. The product assimilates surface pressure and marine wind observations.

\section{Seasonal variability of surface conditions in the CLR}

The purpose of this section is to describe the seasonal atmospheric and ocean surface conditions in the CLR.

The seasonal variability of SST, surface winds stress, horizontal current intensity, depth of the $20^{\circ} \mathrm{C}$ isotherm (hereafter referred to as z20), and the surface net heat flux from monthly averaged model outputs in the CLR for each year from 1998 to 2008 and averaged over the period is shown in Fig. 1. The reliability of the model is also provided by comparing the simulated and the corresponding TMI SST climatological seasonal cycle in the CLR (Fig. 1a). The SST variations display an annual cycle with the highest temperature at the end of boreal winter to the beginning of boreal spring (warm season), when the ITCZ reaches its southernmost position and the trade winds are weakest, and minimum values in boreal summer (cold season), when the trades intensify. The most salient features of the atmospheric and hydrographic fields during May-June are also illustrated in Fig. 1 by May-June averaged maps. Despite a warm bias $\left(\sim 1^{\circ} \mathrm{C}\right)$ compared to satellite observations, the model reproduces the satellite pattern well. While this warm bias in the eastern tropical Atlantic is well known in coupled climate models (e.g., Zeng et al., 1996; Davey et al., 2002; Deser et al., 2006; Chang et al., 2007; Richter and Xie, 2008), results from Large and Danabasoglu (2006) indeed suggest that a warm SST bias may also be present along the Atlantic coast of southern Africa in forced ocean-only simulation. The SST May-June average map indicates that the boreal summer SST minimum is related to intensified cool SST around $6^{\circ} \mathrm{S}$ in the Congo mouth region. In this region, the coast is oriented parallel to the trade flow, which reinforces in boreal summer and is thus favorable to coastal upwelling processes. The mean alongshore wind stress during May-June reveals that upwelling conditions are observed over most of the CLR. The coastal upwelling could also interact with the coastal Kelvin wave propagation (e.g., Ostrowski et al., 2009) highlighted by minimum z20 values in Fig. 1 d.

Wind stress magnitude exhibits a semiannual variability with a second maximum in October-December and a weakening during the July-September season (Fig. 1b). The strengthening of winds in boreal spring is associated with a strengthening of mean current speed, particularly off Cape Lopez between 2 and $4^{\circ} \mathrm{S}$ and west of $8^{\circ} \mathrm{E}$ in May-June (Fig. 1c). The orientation of the surface current is mostly westward for the May-June season, while it is northward from October to January (not shown). This general picture of surface circulation is consistent with observations (Merle, 1972; Piton, 1988; Rouault et al., 2009).

The region is also characterized by a shallow thermocline, which depicts a strong semiannual cycle (Fig. 1d). The evolution of z20 reveals a shoaling of the thermocline during May-July and a deepening up to October-November when it exhibits a maximum depth, in agreement with previous stud- 
ies such as Schouten et al. (2005), who find a similar seasonal cycle from SSH altimetric data.

The surface net heat flux exhibits a maximum in boreal winter and a minimum in July (Fig. 1e), following the seasonal cycle of solar shortwave radiation. As is visible on the May-June average map, greater heating is found over cool waters due to weaker heat loss via latent heat flux in these areas.

The seasonal cycle is modulated by strong year-to-year variations. The mean SST in the CLR in 2005 cools as early as March in TMI data and April in the model data. SST reaches lower values than the climatologic ones, as observed by Marin et al. (2009) and Caniaux et al. (2011) west of $4^{\circ} \mathrm{E}$. This 2005 cold anomaly is associated with positive wind speed and a surface current speed anomaly in April-May (Fig. 1b, c) as well as shallower-than-average thermocline depth. In 2006, SST variations are very close to the climatologic ones.

Thus, the April-June season in the CLR appears as a transitional period characterized by strong seasonal evolution, primarily governed by the local winds, which generate coastal upwelling in the Congo mouth region and are modulated by the variation of thermocline depth.

\section{Analysis of cooling episodes in the CLR in 2005 and 2006}

In this section, we examine the impact of intraseasonal wind bursts on SST in the CLR during the particular years 2005 and 2006 (Marin et al., 2009; Caniaux et al., 2011). We propose analyzing in detail the SST conditions in the CLR east of $5^{\circ} \mathrm{E}$ for both years.

\subsection{SST variations}

In order to delineate the sequence of cooling episodes, we analyze the SST variations from 2-day averaged model outputs in 2005 and 2006 over the CLR, i.e., between 5 and $12^{\circ}$ E. Both the SST (Fig. 3a, c) and intraseasonal variations of SST (Fig. 4a \& f) are shown. The cooling episodes occurred east of $5^{\circ} \mathrm{E}$ from April to September. In 2005, the intraseasonal cooling episodes took place on 8-12 May, 1622 May, 30 May-6 June, and 12-16 June, whereas in 2006, they took place on 20-30 April, 14-24 May, 14-20 June, and 26-30 June. The temperature drop for the two years ranged between -0.2 and $-2{ }^{\circ} \mathrm{C}$. The cooling episodes concerned especially the southern equatorial region (around $\sim 3-4^{\circ} \mathrm{S}$ ), except for the strongest events in which they reached more northern equatorial regions, especially for the mid-May and late May 2005 events. These latter events were associated with an intense SST front between the cold water south of the Equator and the warmer water north of the Equator, as is visible on the SST map for 12 May 2005 presented in Fig. 2. We can see cold waters extending along the eastern coast and in the $\mathrm{ACT}$ region west of $5^{\circ} \mathrm{W}$. In the model, cold waters are deflected offshore of Cape Lopez due to the recursive bias in warm water intrusion toward the south.

Model SST fields (Fig. 3a) indicate that the SST minimum $\left(\sim 24^{\circ} \mathrm{C}\right)$ in 2005 was reached in July, i.e., 1 month earlier than in 2006, as also noticed in seasonal variations of SST averaged in the region (Fig. 1a). These results illustrate the important role of the succession of quick and intense cooling episodes in the establishment of persistent cold anomalies in the CLR, as highlighted by Marin et al. (2009) in the equatorial region.

\subsection{Forcing mechanisms}

\subsubsection{Local forcing}

To examine the local forcing mechanisms responsible for the observed cooling episodes in the CLR, the intraseasonal variations of wind stress magnitude are examined and compared in 2005 and 2006 (Fig. 4b, g). In 2005, successive periods of 6-16 days of wind intensification occurred from late March to late June. The main cooling episodes described above are associated with positive intraseasonal wind stress speed occurring on 6-8, 14-18, and 26-30 May, 10-14 June, and 28 June-2 July with a maximum for the 14-18 May event peaking on 16 May (at $\sim 0.025 \mathrm{~N} \mathrm{~m}^{-2}$ ). Another period of wind intensification is evident in late March-early April but it did not generate significant cooling despite comparable or even higher wind intensity than following wind events. In 2006, periods of wind intensification extended from midMarch to July. The main wind events in boreal spring occurred on 2-4 and 16-24 April, 6-8 and 14-20 May, and 1416 and 24-26 June with maximum intraseasonal wind stress magnitude on 16-24 April $\left(0.019 \mathrm{~N} \mathrm{~m}^{-2}\right)$ and 24-26 June $\left(0.022 \mathrm{~N} \mathrm{~m}^{-2}\right)$. Also, the wind event in late April $2006 \mathrm{did}$ not generate a surface cooling as strong as the mid-May 2006 one, despite higher wind stress magnitude. To depict the subsurface conditions during cooling episodes in the CLR for both years, the $20^{\circ} \mathrm{C}$ isotherm depths averaged from 5 to $12^{\circ} \mathrm{E}$ are presented in Fig. $3 \mathrm{~b}$ and d. They indicate strong correlation with SST variations on an intraseasonal timescale with minimum depths $(<35 \mathrm{~m})$ observed during the midMay 2005 and end May event. In early April 2005 and before late April 2006, the thermocline was deeper, which can explain why wind intensification did not generate a surface cooling at these times. Indeed, at the time of the strong 1624 April 2006 wind event, the z20 values were higher south of the Equator than during the 14-16 May 2005 event, making the SST less reactive to comparable wind intensification. The same feature is observed in early May 2006, when the higher z20 values indicate a deeper thermocline south of the Equator around $3-4^{\circ} \mathrm{S}$ than a few days later. The thermocline appeared shallower south of the Equator in 2005 than in 2006, in agreement with the difference in the cooling intensity observed between the two years. 
(a)

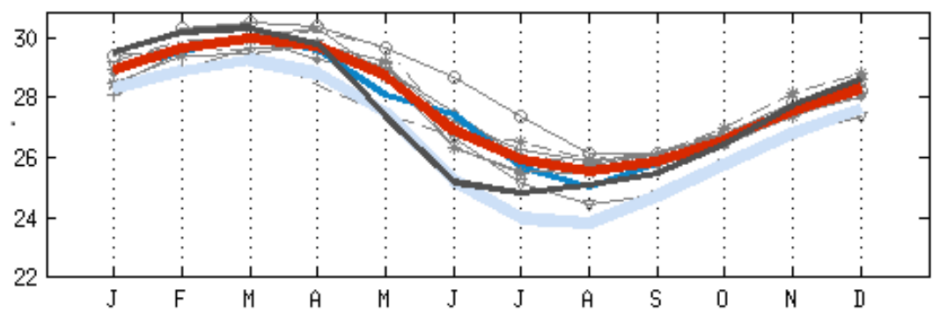

(b)

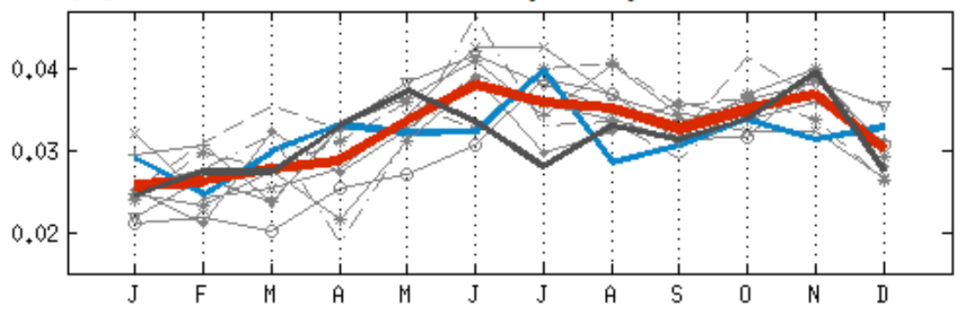

(c)

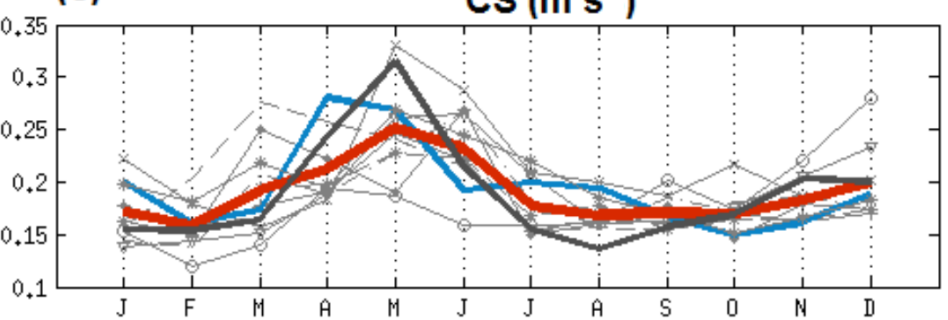

(d)

$\mathrm{Z20}(\mathrm{m})$

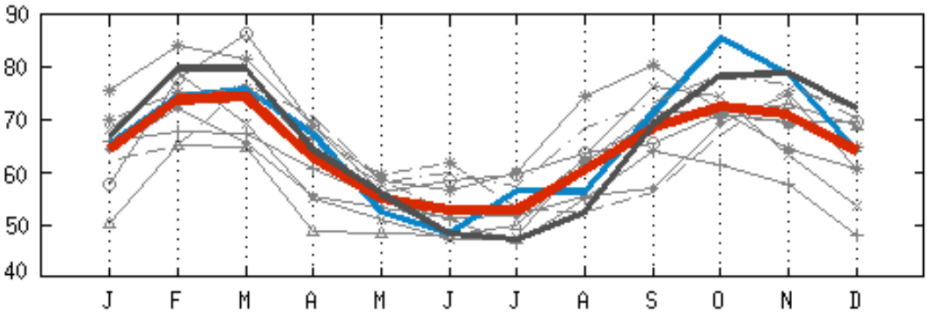

(e)

SST $\left({ }^{\circ} \mathrm{C}\right)$

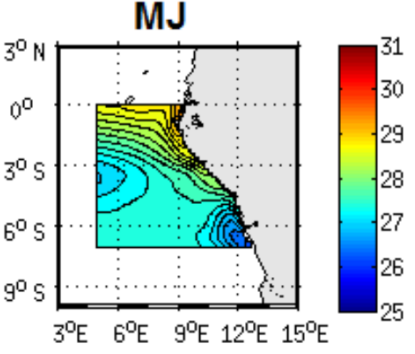

MJ

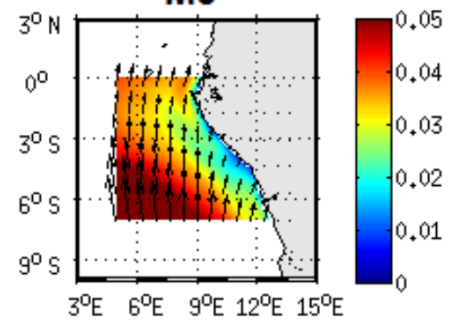

MJ

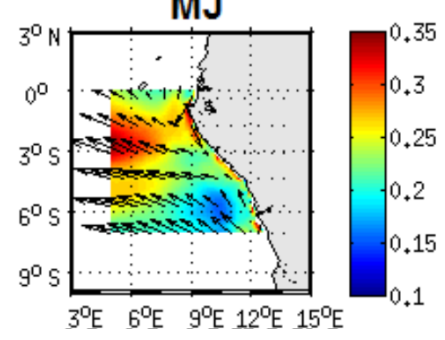

MJ

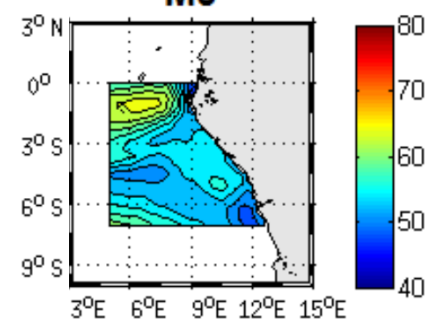

MJ

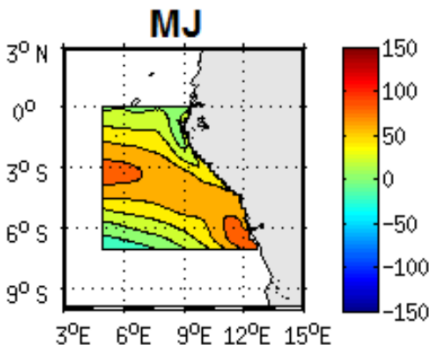

Figure 1. Monthly average of (a) sea surface temperature $\left({ }^{\circ} \mathrm{C}\right),(\mathbf{b})$ wind stress direction (vectors) and magnitude (color field) $\left(\mathrm{N} \mathrm{m}{ }^{-2}\right.$ ), (c) horizontal surface current direction (vectors) and speed (color field) $\left(\mathrm{m} \mathrm{s}^{-1}\right)$, (d) $20^{\circ} \mathrm{C}$ isotherm depth (m), and (e) surface heat flux ( $\mathrm{W} \mathrm{m}^{-2}$; positive values indicate downward flux) from January to December 1998 to 2008 and for the climatology (averaged over 19982008) simulated by the model (red curve) and from the observations; monthly average TMI 3-daily SST data (light blue curve in a) averaged over $5-14^{\circ} \mathrm{E}$ and $7-0^{\circ} \mathrm{S}$. Right panels: maps of each variable over May-June. 
(a)

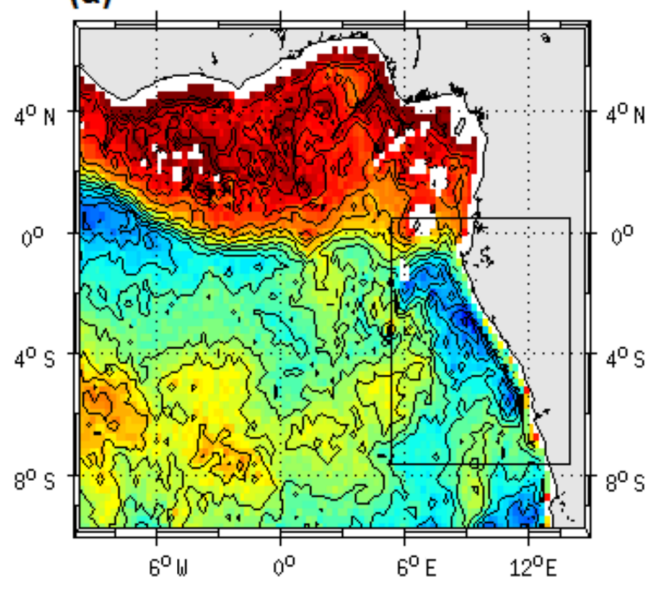

(b)

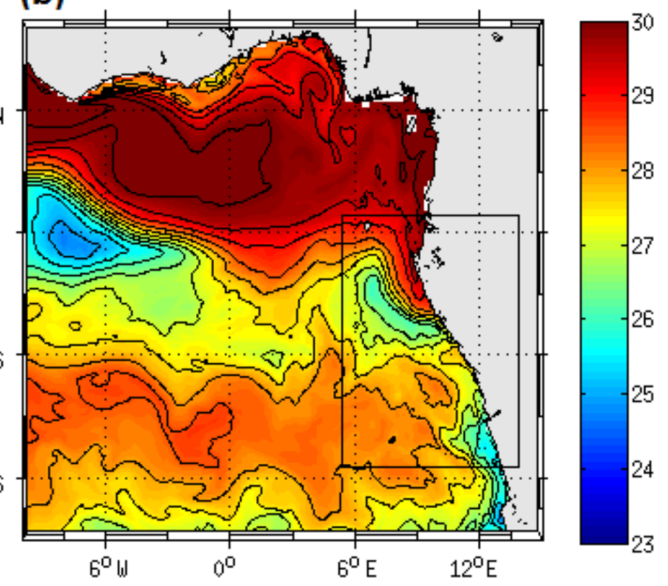

Figure 2. Map of the sea surface temperature $\left({ }^{\circ} \mathrm{C}\right)$ on 12 May 2005 from 3-day average TMI data (a) and from the 2-day average model output (b). Note that for the model it corresponds to the 11-12 May average, whereas for TMI data it is the 10-12 May average. The black square indicates the Cape Lopez region (called the "CLR").

The Ekman pumping velocity $w_{\mathrm{e}}$ averaged over the CLR for 2005 and 2006 is shown in Fig. 4d and i, respectively. The dates of intraseasonal upward velocities are quite well correlated with the dates of intraseasonal wind events (with correlation coefficients equal to 0.55 for 2005 and 0.41 for 2006), with the maximum during the early April, mid-May, and end May 2005 events and during late April, mid-June, and end June 2006. However, for comparable wind intensification, the boreal spring and summer wind events were not associated with comparable intensity of Ekman pumping velocity.

Another process that may contribute to cooling in the upper layer is vertical mixing due to the intense vertical shear of the current. The maximum of the vertical shear magnitude fields in the CLR, averaged between 5 and $12^{\circ} \mathrm{E}$ for 2005 and 2006 (Fig. 4c, h), exhibited intensification south of the Equator centered around 3-4 $4^{\circ}$. Weaker intensification also occurred occasionally at the Equator (located around $80 \mathrm{~m}$ of depth between the westward surface South Equatorial Current (SEC) and the eastward subsurface equatorial undercurrent). Around $3-4^{\circ} \mathrm{S}$, the vertical shear was driven by the SEC and reinforced by prevailing southerly wind events through Ekman transport. It thus occurred on the date of wind events previously identified for 2005 and 2006, with stronger vertical shear occurring in early May 2005 and late April 2006. The intensity of the maximum of vertical shear magnitude during the events was quite similar between 2005 and 2006. The main difference was in their meridional extent related to the meridional extent of the strengthened southerly winds, which reached the equatorial region during the May 2005 events (not shown). We can also notice that for comparable wind intensification, the boreal spring and summer wind events were not associated with comparable intensity of vertical shear. The meridional wind component favorable to westward Ekman transport was actually stronger during April and May events than during summer ones (not shown).

The heat content within the mixed layer is also impacted by sea surface heat fluxes. The net heat fluxes averaged between 5 and $12^{\circ} \mathrm{E}$ are shown in Fig. $4 \mathrm{e}$ and $\mathrm{j}$ for 2005 and 2006, respectively. They indicate a net heating $(\sim 50$ $100 \mathrm{~W} \mathrm{~m}^{-2}$ ) over the $2-5^{\circ} \mathrm{S}$ latitude band, where the SST cooling was strongest, suggesting other mechanisms involved. However, we notice some particular events during which the net heat flux was negative over most of the region. A strong net cooling $\left(-30 \mathrm{~W} \mathrm{~m}^{-2}\right)$ occurred during the 26-28 May 2005 event. It was mainly due to a sudden decrease in incoming surface shortwave radiation (drop of about $80 \mathrm{~W} \mathrm{~m}^{-2}$ in the CLR between 22 and 28 May; not shown), suggesting increased cloud cover. Another strong net cooling occurred on 2 April 2006 with a mean value in the CLR reaching $-95 \mathrm{Wm}^{-2}$. It is more sudden than the end May 2005 one and was almost exclusively restricted to the CLR with local values reaching $-185 \mathrm{~W} \mathrm{~m}^{-2}$ (not shown). For both events, the net cooling did not concern the equatorial region west of $0^{\circ} \mathrm{W}$.

\subsubsection{Remote forcing}

\section{Highlighting of Kelvin wave propagation}

As previously shown, the time of occurrence of the cold events in the CLR coincides with a shallow thermocline, which contributes to making the mixed layer temperature more reactive to surface forcing (note that $\mathrm{z} 20$ does not necessarily show the same variability as the mixed layer depth). Indeed, because of its proximity to the Equator, the thermocline in the CLR is affected by the arrival of equatorial waves initiated in the western part of the basin. Pairs of 
(a)

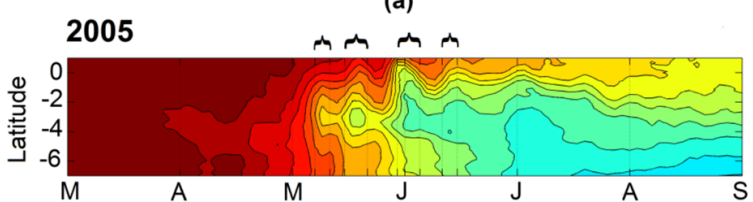

(b)

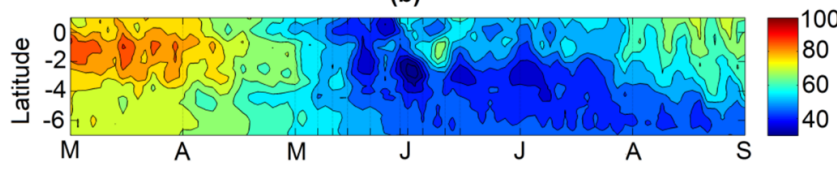

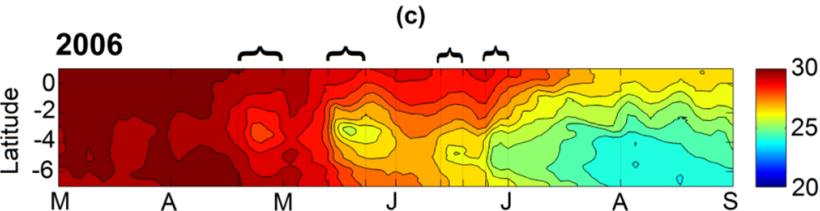

(d)

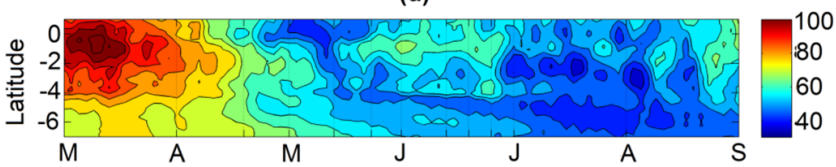

Figure 3. (a, c) Latitude-time diagram of the sea surface temperature $\left({ }^{\circ} \mathrm{C}\right)$ averaged between 5 and $12^{\circ} \mathrm{E}$; (b, d) latitude-time diagram of the $20^{\circ} \mathrm{C}$ isotherm depth (m) averaged between 5 and $12^{\circ} \mathrm{E}$ from 1 March to 31 August 2005 (left panels) and 2006 (right panels). The cooling episodes are indicated by the black brackets.

2005

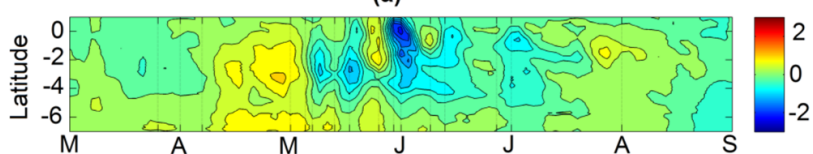

(b)

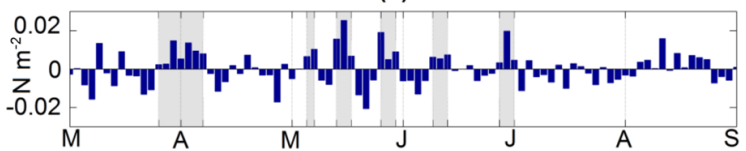

(c)

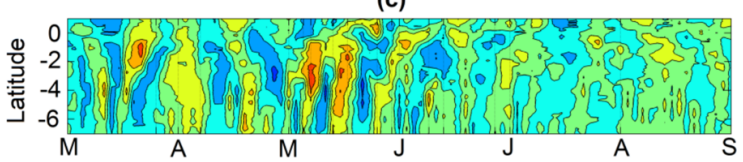

(d)

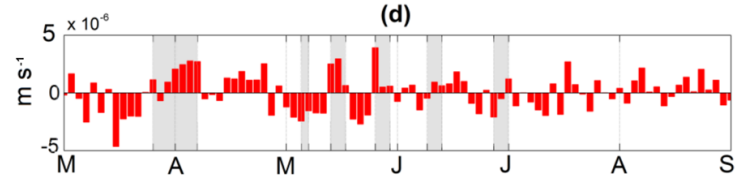

(e)

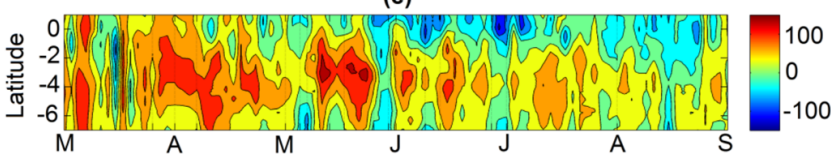

2006

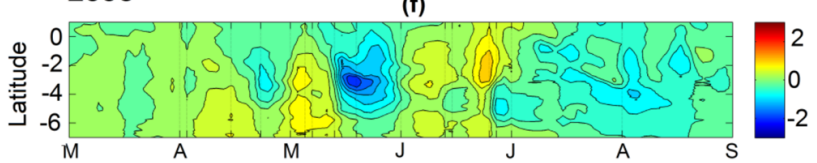

(g)

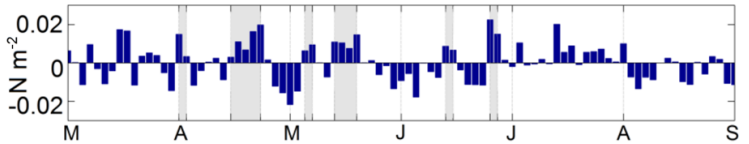

(h)

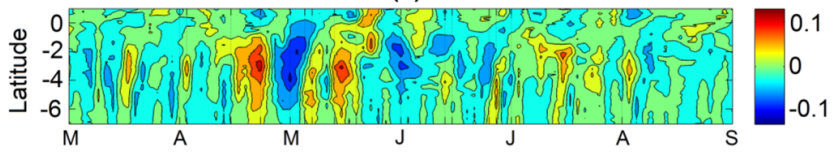

(i)

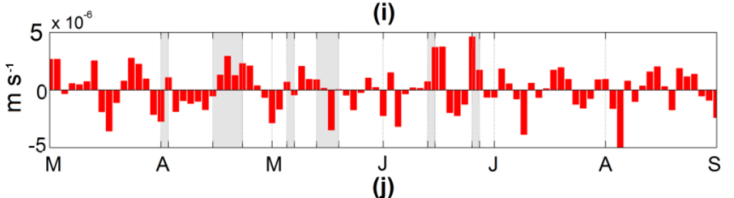

(j)

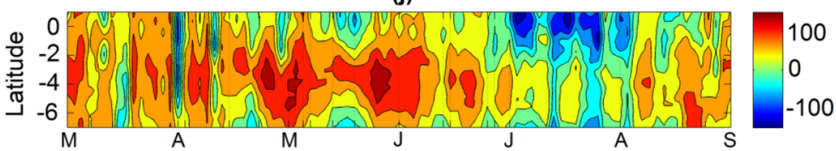

Figure 4. (a and f) Time-latitude diagram from $7^{\circ} \mathrm{S}$ to $1^{\circ} \mathrm{N}$ of the intraseasonal variations of sea surface temperature (in ${ }^{\circ} \mathrm{C}$ ) averaged between 5 and $12^{\circ} \mathrm{E}$; (b and $\mathbf{g}$ ) time evolution of the intraseasonal variations of wind stress amplitude $\left(\mathrm{N} \mathrm{m}^{-2}\right)$ averaged between 5 and $12^{\circ} \mathrm{E}$ and between 3 and $0^{\circ} \mathrm{S}$; (c and $\mathbf{h}$ ) latitude-time diagram of the intraseasonal variations of the maximum of the current vertical shear magnitude $\left(\mathrm{m} \mathrm{s}^{-1}\right)$ averaged between 5 and $12^{\circ} \mathrm{E}$; ( $\mathbf{d}$ and $\left.\mathbf{i}\right)$ longitude-time diagram of the intraseasonal variations of Ekman pumping $\left(\mathrm{m} \mathrm{s}^{-1}\right)$ averaged over the CLR. Ekman pumping values $>0$ indicate upwelling; (e and $\left.\mathbf{j}\right)$ latitude-time diagram of the net heat flux (W $\mathrm{m}^{-2}$ ) averaged between 5 and $12^{\circ} \mathrm{E}$ from 1 March to 31 August 2005 (left panels) and 2006 (right panels). For details about calculations of intraseasonal variations, see Sect. 2 . The intraseasonal southerly wind events are indicated by the shaded areas. Note that the cooling episodes occur a few days after the southerly wind events.

alternate downwelling and upwelling Kelvin waves usually occur in February-March, July-September, and OctoberNovember. Upon impingement with the eastern boundary, the incoming equatorial Kelvin wave excites westwardpropagating Rossby waves and poleward-propagating coastal Kelvin waves (Moore, 1968; Moore and Philander, 1977; Illig et al., 2004; Schouten et al., 2005; Polo et al., 2008). The $20^{\circ} \mathrm{C}$ isotherm depth anomalies along the Equator and along $9^{\circ} \mathrm{E}$ are presented in Fig. 5 and clearly evidence large negative anomalies, indicating a shallower-than-average thermocline propagating eastward along the Equator and then southeastward for both years. The eastward propagation of Kelvin waves along the Equator and southeastward along the coast is also visible in the basin-wide SSH anomalies (Fig. 6) with a phase velocity of about $1.1-1.3 \mathrm{~m} \mathrm{~s}^{-1}$, which fits well in the range between the second and third baroclinic equato- 
rial Kelvin wave modes. In 2005, negative SSH and z20 anomalies occurred in the west in early March-early April and in mid-May, whereas they occurred around late February to mid-March and early May and June in 2006. The first Kelvin wave thus reached the CLR slightly earlier in 2006 than 2005, at the beginning of May. In addition, the two upwelling Kelvin waves followed each other more closely in 2005 than in 2006.

Thus, the intensity of the cold events observed in boreal spring and summer 2005 and 2006 resulted from both the basin preconditioning by remotely forced shoaling of the thermocline, local mixing and upwelling processes in response to strong southerly local winds, and heat flux variations. In 2005, stronger wind intensification and favorably preconditioned oceanic subsurface conditions made the coupling between surface and subsurface ocean processes more efficient than in 2006, resulting in stronger cooling.

\section{Kelvin wave generation and coinciding atmospheric conditions in the west}

In order to identify the wind activity that accompanies the generation of Kelvin upwelling waves in winter 2005 and 2006 in the western part of the basin, we analyze the position of the ITCZ (averaged over $50-35^{\circ} \mathrm{W}$ ) identified as the latitude at which the meridional wind stress goes to zero (Fig. 7a, g). The intraseasonal anomaly of the zonal and meridional components of the wind stress (Fig. $7 \mathrm{~b}-\mathrm{c}$ and $\mathrm{h}-$ i), the intraseasonal anomaly of wind stress curl (Fig. 7d, j), and the intraseasonal anomaly of the $\mathrm{z} 20$ and SSH (Fig. 7e-f, $\mathrm{k}-\mathrm{l}$ ) averaged in the equatorial band (over $1^{\circ} \mathrm{S}$ and $1^{\circ} \mathrm{N}$ ) are also presented. Many authors suggest that the source of equatorial Kelvin waves is mainly related to a sudden change in the western equatorial zonal wind (e.g., Picaut, 1983; Philander, 1990): a symmetric westerly (easterly) wind burst along the Equator will generate Ekman convergence (divergence) and thus force downwelling (upwelling) anomalies that then propagate eastward as a Kelvin wave (Battisti, 1988; Giese and Harrison, 1990). In 2005, a shallower-than-average thermocline, evidenced by negative z20 and SSH anomalies, occurred at the end of March-beginning of April in the west part of the basin (Fig. 7e, f). The intraseasonal anomalies of meridional and zonal wind stress indicate that the maximum of thermocline slope anomaly was associated with a strengthening of northeast trades followed by a strengthening of southeast trades from either side of the Equator. At the Equator, we indeed notice a sudden reversing of meridional winds that turned southward on 27-28 March 2005 related to an abrupt southward displacement of the ITCZ, which was then found south of the Equator in the west part of the basin (Fig. 7a, b). The ITCZ returned to its initial position 4 days later followed by a strengthening of easterlies that persisted for $\sim 20$ days (Fig. 7c). Climatologically, the latitudinal position of the ITCZ varies from a minimum close to the Equator in boreal spring (March-May) in the west to a maximum extension of $10-15^{\circ} \mathrm{N}$ in late boreal summer (August) in the east. Positive (negative) wind stress curl is found north (south) of the ITCZ. When the ITCZ is north of the Equator, it induces upward (downward) Ekman pumping to the north (south) of the ITCZ. Thus, the southward shift of the ITCZ on 27-28 March 2005 accompanied by strong northerlies led to a negative anomaly of wind stress curl south of the Equator, resulting in upward Ekman pumping. Results indeed show a strong negative anomaly on 22-26 March 2005 associated with the southward shift of the ITCZ just before the upwelling signal, initiated on 28 March. These changes contributed to a rise in the oceanic thermocline with a time lag of some days (Fig. 7e, f). The upwelling signal might then be reinforced by the symmetric easterly wind that concerned a large part of the western basin. In addition, we identify in Fig. $7 \mathrm{~d}$ another peak of negative wind stress curl anomaly on 6-8 May 2005, more sudden than the previous winter one. It was associated with negative z20 SSH anomalies indicative of a thermocline rise initiated on 6 May 2005 in the west of the basin that propagated eastward along the Equator. The zonal wind stress anomalies (Fig. 7c) also indicate an easterly wind strengthening initiated at the beginning of May, with a maximum on $8-10$ May just after the minimum of wind stress curl.

In 2006, the upwelling Kelvin wave is identified in the first half of March in the west part of the basin (Fig. 7k, 1). The coinciding atmospheric conditions were slightly different than the ones identified in 2005. In winter, the position of the ITCZ had a more southern position in 2006 than in 2005. It crossed the Equator during a longer period (about 10 days from $\sim 10$ February 2006), reaching minimum latitude on 22-24 February. This location south of the Equator induced a negative wind stress curl anomaly (Fig. 7j). As in 2005, the reversion of the meridional wind at the Equator was followed by a strengthening of the westward component of the wind stress a few days after, which lasted for about 10 days (Fig. 7i); however, it was of a lesser magnitude compared to 2005 and only concerned the westernmost part of the basin. In addition, the negative zonal wind anomaly concerned mainly the northeasterlies rather than the southeasterlies, leading to an antisymmetric meridional wind pattern as well as a symmetric zonal wind pattern on either side of the Equator (not shown). These wind patterns were expected to generate Ekman divergence at the Equator and thus to reinforce the observed upwelling anomalies.

Thus, for both years, upwelling Kelvin waves were generated in the west, while easterly winds were strengthened from either side of the Equator after the ITCZ reached its southernmost location. This latter was observed 1 month earlier in 2006 than in 2005 and was associated with a negative wind stress curl anomaly. In winter 2005, the ITCZ was found south of the Equator after a very sudden southward shift and was followed by strong easterlies during $\sim 20$ days, while in winter 2006, the ITCZ was found closer to the Equator less sharply and during a longer period, followed by weaker east- 
(a) 2005

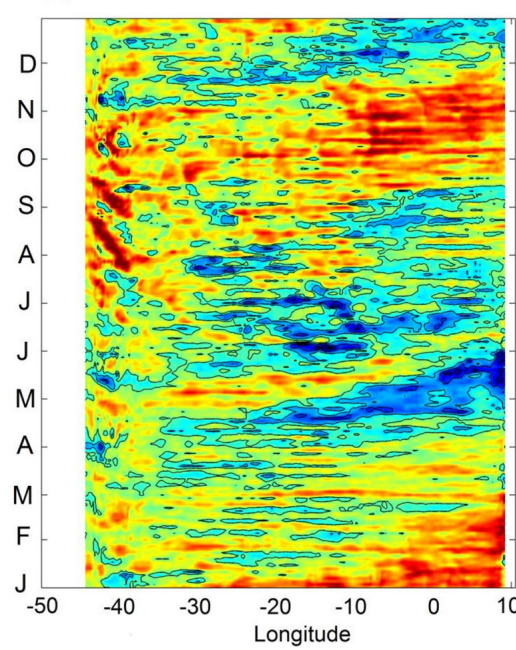

(b) 2006

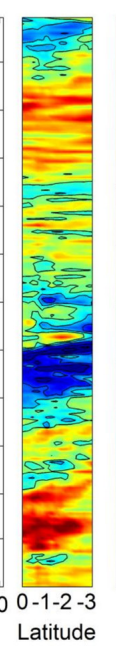

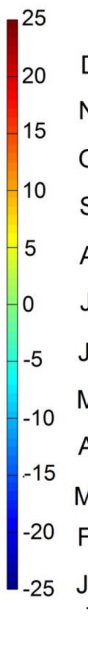

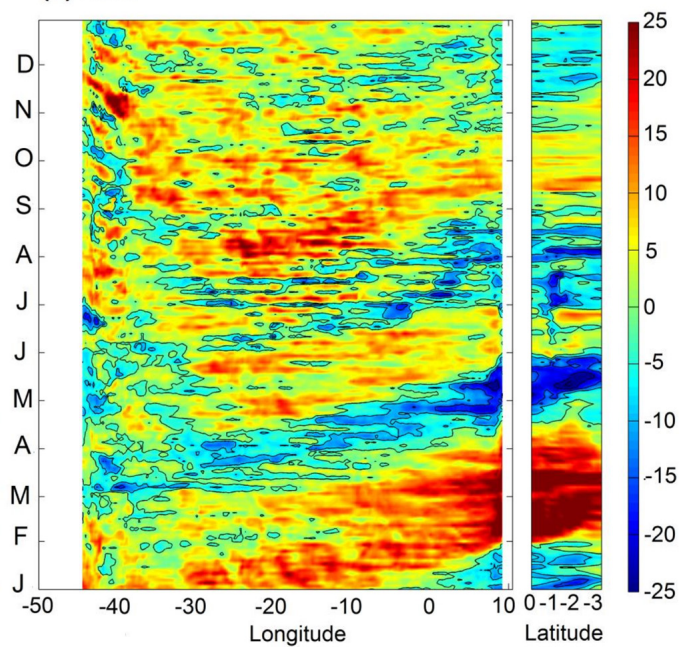

Figure 5. Time evolution of the intraseasonal anomaly of $20^{\circ} \mathrm{C}$ isotherm depth (m) along the Equator (between $54^{\circ} \mathrm{W}$ and $12^{\circ} \mathrm{E}$ ) and along $9^{\circ} \mathrm{E}$ (between the Equator and $3^{\circ} \mathrm{S}$ ) for 2005 (a) and 2006 (b). Negative values indicate a $20^{\circ} \mathrm{C}$ isotherm depth closer to the surface. For details about calculations of the anomalies, see Sect. 2.

(a) 2005

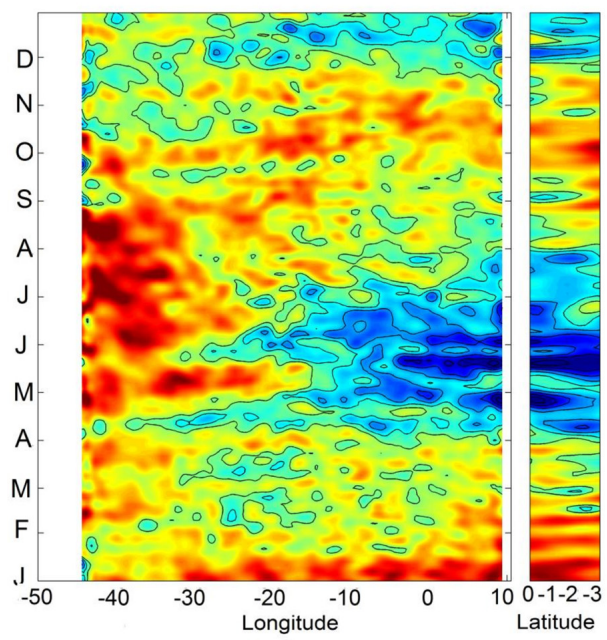

(b) 2006

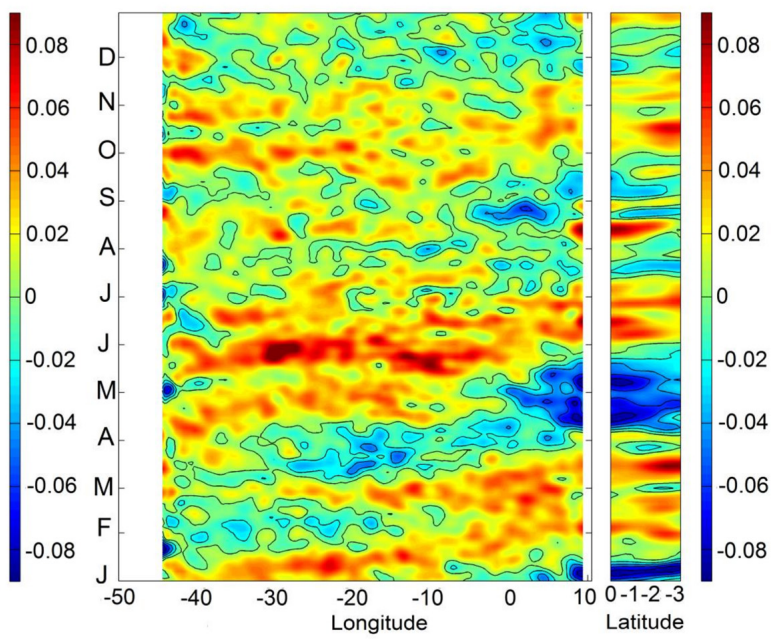

Figure 6. Time evolution of the sea level anomaly $(\mathrm{m})$ along the Equator (between $54^{\circ} \mathrm{W}$ and $12^{\circ} \mathrm{E}$ ) and along $9^{\circ} \mathrm{E}$ (between the Equator and $3^{\circ} \mathrm{S}$ ) for 2005 (a) and 2006 (b) from AVISO data.

erlies compared to 2005. These results highlight another way in which intraseasonal wind events may impact the SST variability in the eastern part of the basin through the generation of a Kelvin wave in the west, which shoals the thermocline in the east a few weeks later.

\subsection{Westward extension of the CLR cooling}

In the east, the cooling generated by southerly wind bursts in the CLR then progressively extended westward to connect with the southern boundary of the equatorial ACT. This phenomenon was more obvious in 2005 when the cooling that first concerned the coastal area extended further offshore a few days after the two strong events occurring in the second half of May. To evidence the effect of these events on SST, maps of intraseasonal SST anomaly and intraseasonal wind stress anomaly averaged from 1 to 12 May (before the strong 2005 events; Fig. 8a) and from 14 to 31 May (during and after the strong 2005 events; Fig. 8b) are presented in Fig. 8 . The same calculations have been made for 2006 for comparison. The results illustrate an enhancement after 10 May of the cooling in the east associated with southerly wind intensification and an extension of the cooling, especially south of the Equator up to $20^{\circ} \mathrm{W}$. 


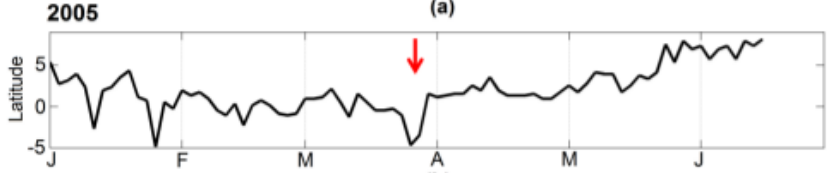

(b)
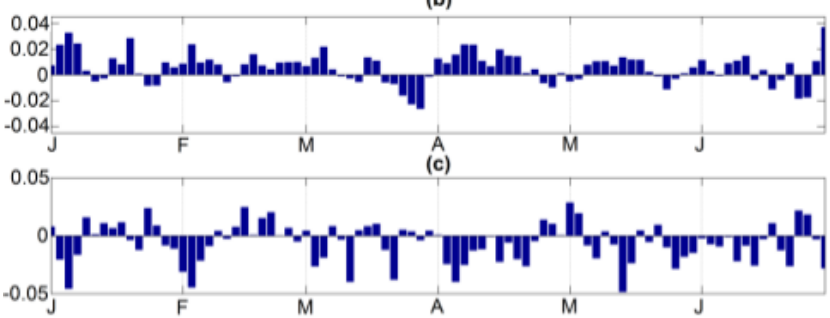

(d)

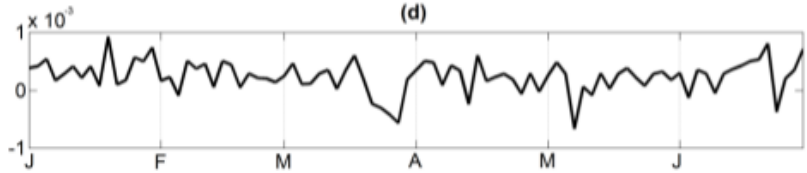

(e)
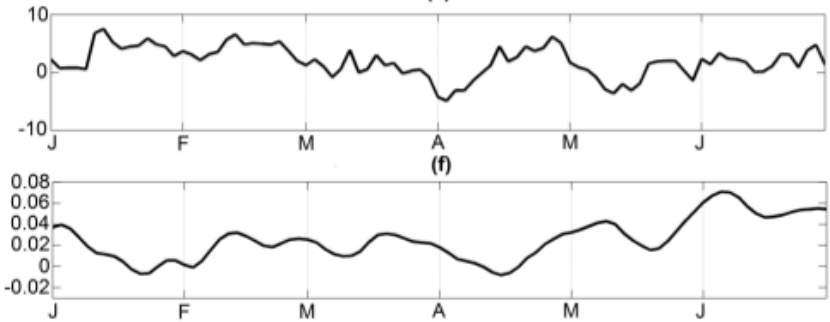

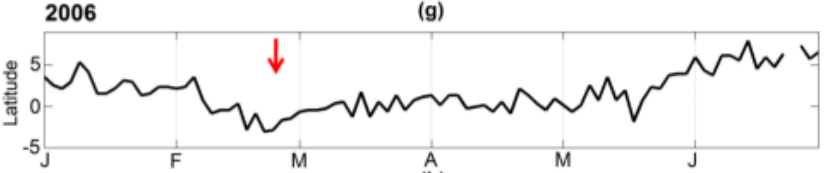

A
(h)

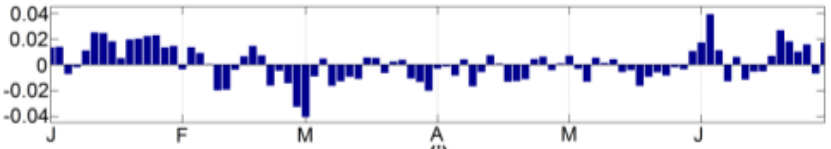

(i)

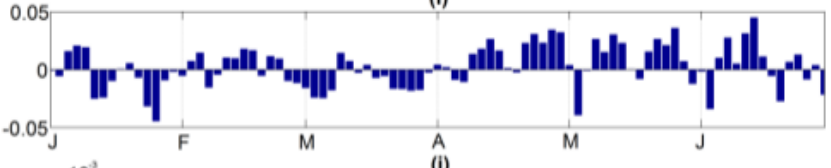

$\times 10^{3}$

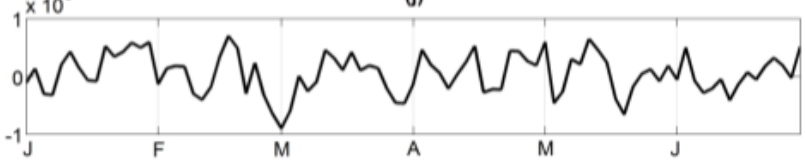

(k)
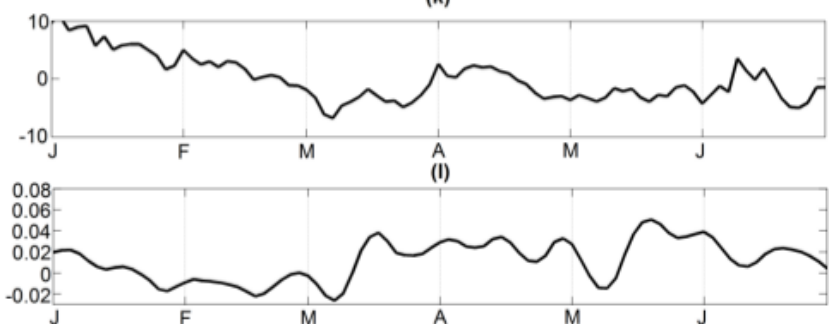

Figure 7. Time evolution from 2-day averaged model outputs over January-June 2005 (a-f) and January-June 2006 (g-l) of the following: $(\mathbf{a}, \mathbf{g})$ the position (in latitude, between $5^{\circ} \mathrm{S}$ and $10^{\circ} \mathrm{N}$ ) where the meridional wind stress value equals zero (indicator of the position of the ITCZ); $(\mathbf{b}, \mathbf{h})$ the intraseasonal anomaly of the meridional wind stress $\left(\mathrm{N} \mathrm{m}^{-2}\right)$ averaged between 50 and $35^{\circ} \mathrm{W}$ and between $1^{\circ} \mathrm{S}$ and $1^{\circ} \mathrm{N}$; $(\mathbf{c}, \mathbf{i})$ same as $(\mathbf{b}, \mathbf{h})$ but for intraseasonal anomaly of zonal wind stress $\left(\mathrm{N} \mathrm{m}^{-2}\right) ;(\mathbf{d}, \mathbf{j})$ the intraseasonal anomaly of the wind stress curl $\left(\mathrm{N} \mathrm{m}^{-2}\right)$; (e, $\left.\mathbf{k}\right)$ the intraseasonal anomaly of the $20^{\circ} \mathrm{C}$ isotherm depth ( $\mathrm{m}$; negative values indicate that the $20^{\circ} \mathrm{C}$ isotherm depth is closer to the surface); and (f, l) the intraseasonal anomaly of the sea level (m). The red arrow in (a, g) indicates the southward shift of the ITCZ before the generation of the Kelvin wave (see text). For details about the calculations of anomalies, see Sect. 2.

(a)
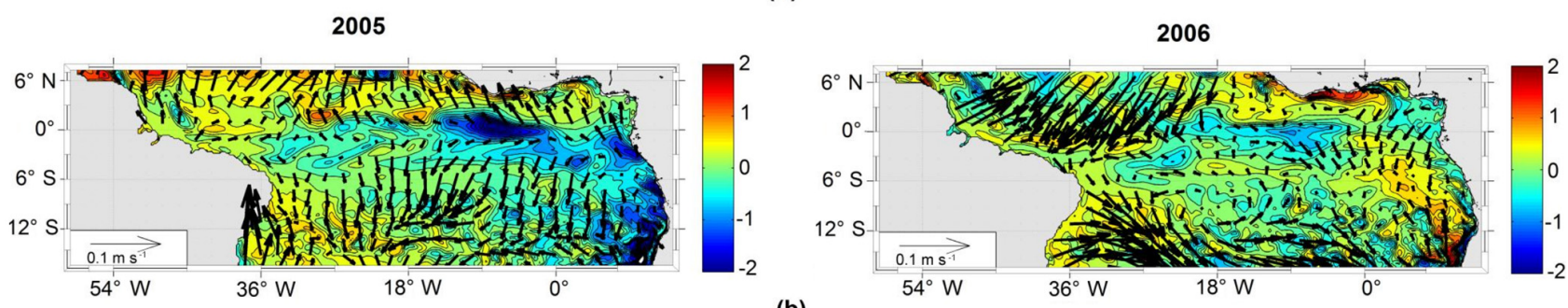

(b)
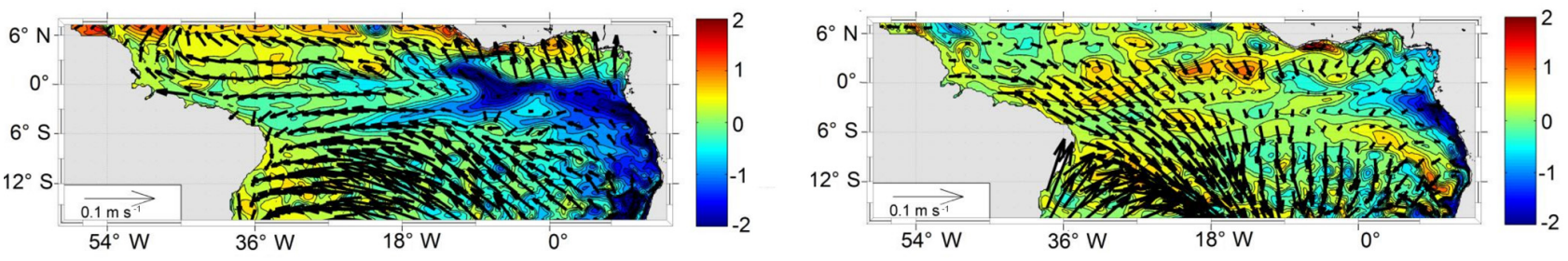

Figure 8. (a) Intraseasonal anomaly of sea surface temperature $\left({ }^{\circ} \mathrm{C}\right.$; color) superimposed with intraseasonal anomaly of wind stress intensity (arrows) averaged over 1-12 May 2005 (a) and over 14-30 May (a); (b) same but for 2006. For details about the calculations of the anomalies, see Sect. 2. 
To better understand the oceanic processes implied in this cooling extension, we compared the SST, z20, SLA, and zonal velocities along $3^{\circ} \mathrm{S}$ from March to September 2005 (Fig. 9a-d) and 2006 (Fig. 9e-h). In 2005, the cooling westward extension was associated with a westward propagation of a shallower thermocline and negative SLA from the African coast up to $5-10^{\circ} \mathrm{W}$ combined with enhanced surface westward current fluctuations on the dates of the successive events from April-June. The fluctuations of the westward surface current occurring off Gabon with periods of $\sim 8-10$ days were related to the strengthening of southerly winds during the wind bursts in the same periods (Fig. 4b, g). The surface current in this area is part of the westward SEC, which is known to intensify during the cold season (Okumura and Xie, 2006). Our study implies shorter timescales than the seasonal scale but the intensification of the SEC during wind bursts through Ekman transport processes might contribute to the westward extension of the cooling by advection of cold eastern upwelled water. This is in agreement with de Coëtlogon et al. (2010), who found from model results that at short timescales (a few days) more than half of the cold SST anomaly around the equatorial cooling could be explained by horizontal oceanic advection controlled by the wind with a lag of a few days. In addition, minimum z20 and SLA values propagating westward at $3^{\circ} \mathrm{S}$ (Fig. 9b, c) initiated from the coast with a propagating speed of around $10 \mathrm{~cm} \mathrm{~s}^{-1}$, which is very close to the phase speed of Rossby waves. Indeed, the generation of the westward waves at the coast coincided with the arrival of Kelvin waves (see Fig. 5a), suggesting the possibility of Kelvin wave reflection processes into symmetrical westward-propagating Rossby waves. A westward propagation of z20 and SLA minimums, although less obvious, was also identified at $3^{\circ} \mathrm{N}$ (not shown).

In 2005 , the locally wind-forced component of the wave might reinforce the remote part of the reflected wave signal at the coast by the sea level slope, which balanced the strengthening of alongshore winds blowing during the midMay and late May events. The quantitative and respective contributions of local and remote wind forcing to this wave is out of the scope of this study and would require further analysis. This phenomenon is supported in 2005 by anomalous eastward-expanded southerly wind bursts observed in May 2005. The month of May is also a period when westward surface currents are usually maximum (as is visible in the mean seasonal cycle shown in Fig. 1c). Thus, the combined effects of westward surface currents (via advection and vertical mixing through horizontal current vertical shear), local wind influences (via vertical mixing), and wave westward propagation resulted in the extension of cold upwelled water from the eastern coast to near $20^{\circ} \mathrm{W}$.

In 2006, the westward extension of cold waters established later, from the beginning of July. A coastal cooling occurred on 18-26 May but no westward extension of the cold waters is observed in this period (Fig. 9e). In 2005, the two upwelling Kelvin waves followed each other closely, while in 2006, the first Kelvin upwelling wave reached the coast in May and the second in July (Figs. 5b, 6b, and 9f). In addition, the intraseasonal wind strengthening responsible for the coastal cooling on 18-26 May 2006 is less intense (wind stress mean in the CLR $\sim 0.04 \mathrm{~N} \mathrm{~m}^{2}$ ) than the one in midMay 2005 ( $\sim 0.06 \mathrm{~N} \mathrm{~m}^{2}$; preceded and followed by another wind burst a few days before and after; Figs. $3 \mathrm{~b}$ and $4 \mathrm{~b}$ ).

The analysis over the 1998-2008 period shows that the westward extension of the cold SST takes place every year but begins at different times of the year (not shown). It occurs generally from June-July, when the cooling events usually occur in the east at this location, and is thus closely linked with the shoaling of the thermocline due to the arrival of a Kelvin upwelling wave at the eastern coast.

In conclusion to this section, the SST variability in the CLR at intraseasonal timescales is the result of a combination between basin preconditioning by remotely forced shoaling of the thermocline via Kelvin waves, local mixing induced by current vertical shear, and upwelling processes in response to strong southerly winds. As highlighted for the 26-28 May 2005 and 2 April 2006 events, the net heat flux may also contribute to cooling the surface waters through enhanced cloud cover that decreases the incoming solar radiation. The cold upwelled waters around $3^{\circ} \mathrm{S}$ then extend westward from the eastern coast to near $20^{\circ} \mathrm{W}$ through the combined effect of westward-propagating Rossby waves and vertical mixing and advection processes. The cool water may thus contribute to the cooling in the southern edge of the cold tongue region. Although the processes implied differ slightly due to the presence of the coast, the SST variability in the CLR is quite close to the one in the equatorial cold tongue region (not shown) due to similar atmospheric forcing. However, for a given wind burst, the intensity of SST response in the CLR and in the cold tongue region is modulated by subsurface conditions that are under the influence of equatorial Kelvin waves. In May 2005, the Kelvin wave reached the eastern coast while three wind bursts occurred. The thermocline was thus shallower in the east than west of $0^{\circ} \mathrm{W}$, providing favorable subsurface conditions and making the coupling between the SST more reactive to wind intensification during this month. In addition, the decreased shortwave radiation due to enhanced cloud cover during the 26-28 May 2005 event and 2 April 2006 event, which contributes to cooling in the CLR, did not concern the equatorial region east of $0^{\circ} \mathrm{W}$.

\section{Focus on the mid-May 2005 event}

We have previously identified five main cold events in 2005 (22-24 April, 8-12, 16-20, 26-30 May, and 14-18 June) characterized by a temperature drop ranging from -0.2 to $-1.7^{\circ} \mathrm{C}$ in the model. Analysis of intraseasonal wind stress magnitude (Fig. 4b) has revealed that each event is associated with strengthening of equatorward winds, especially during the 14-16 May event when the intraseasonal wind 

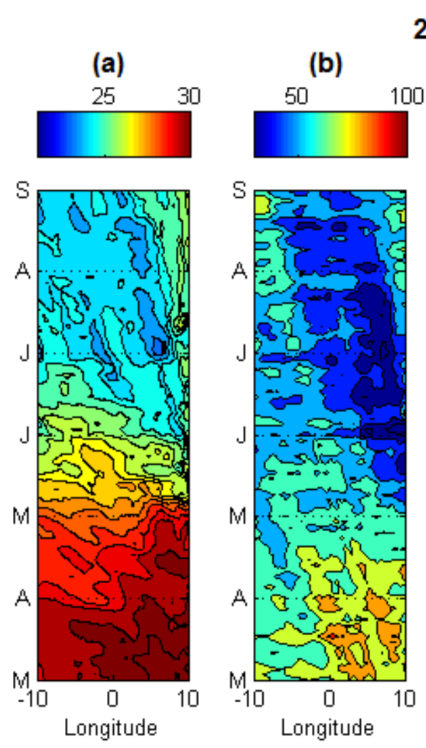

2005

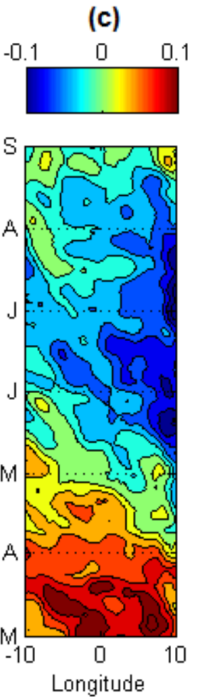

(d)
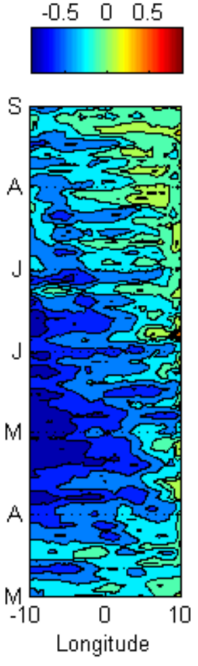

2006
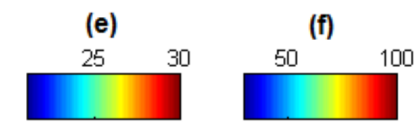

(g)

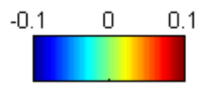

(h)
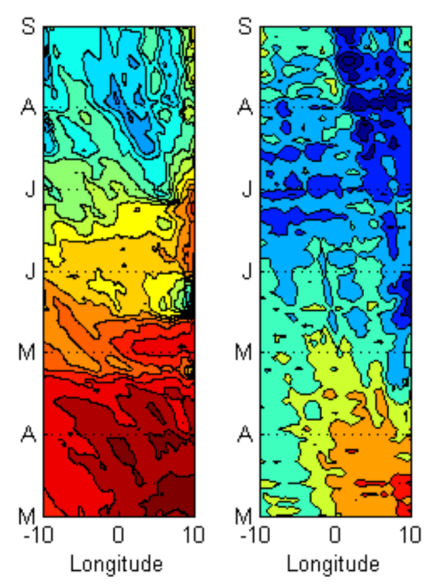

\subsection{Atmospheric conditions}

\subsubsection{Wind and surface atmospheric pressure}

The spatial distribution of the mid-May 2005 wind event can be inferred from Fig. 10 in which CFSR wind speed fields superimposed with daily precipitation fields, surface pressure, wind speed curl, and downward shortwave radiation are presented from 13 to 17 May. The event was characterized by intense southeasterly wind east of $15^{\circ} \mathrm{W}$ and from $30^{\circ} \mathrm{S}$ to the Equator from 13-14 May, concomitant with a strengthening of the easterlies west of $30^{\circ} \mathrm{W}$ between 30 and $15^{\circ} \mathrm{S}$ (Fig. 10a). The strong southeasterly winds then drifted westward until 15-16 May when the maximum was located in the western part of the basin off the northeastern Brazilian coast. Simultaneously, a strengthening of southerly winds occurred north of the Equator in the Gulf of Guinea. The strong winds during the event were associated with the high-pressure core of the St. Helena anticyclone, especially on 13-14 May, also associated with particularly low pressure under the ITCZ 4 days later (Fig. 10c). The pressure fall during the mid-May 2005 event appeared as the lowest in May over the whole decade (not shown). The meridional surface pressure gradient during the event is thus found to be the strongest over the 1998-2008 period. This suggests strong Hadley circulation intensity during the mid-May event and therefore strong equatorward moisture flux, allowing the deep atmospheric convection in the Gulf of Guinea to be triggered at a selfsustaining level (see Sect. 5.2).

\subsubsection{Precipitation}

The maps of precipitation rate during the event (Fig. 10b) display a band of heavy precipitation $\left(9-17 \mathrm{~kg} \mathrm{~m}^{-2}\right.$ day $^{-1}$ ) between 5 and $9^{\circ} \mathrm{N}$ and off northeast Brazil from the coast to $15^{\circ} \mathrm{W}$ and from 10 to $3^{\circ} \mathrm{S}$. The maximum precipitation rate in this region occurred on 15-16 May concomitant with the easterly wind strengthening. This convective zone, located between the ITCZ north of the Equator and the South Atlantic Convergence Zone (SACZ) in the southern tropics, is the southern Intertropical Convergence Zone (SITCZ) (Grodsky and Carton, 2003). This zone usually forms later by June-August when the southern branch of the convection separates from the ITCZ that moves north of the Equator. Grodsky and Carton (2003) showed that this rainfall pattern appears closely linked to the seasonal change in SST difference between the ACT region (which they defined between 15 and $\left.5^{\circ} \mathrm{W}, 2^{\circ} \mathrm{S}-2^{\circ} \mathrm{N}\right)$ and the SITCZ region $\left(25-20^{\circ} \mathrm{W}\right.$, $\left.10-3^{\circ} \mathrm{S}\right)$. They argued that the seasonal appearance of the $\mathrm{ACT}$ along the Equator sets up pressure gradients within the boundary layer that induce wind convergence in the SITCZ region. Based on the Grodsky and Carton (2003) results, the unusual rainfall conditions during the mid-May event might thus be explained by a strong SST gradient between the two 
(a)

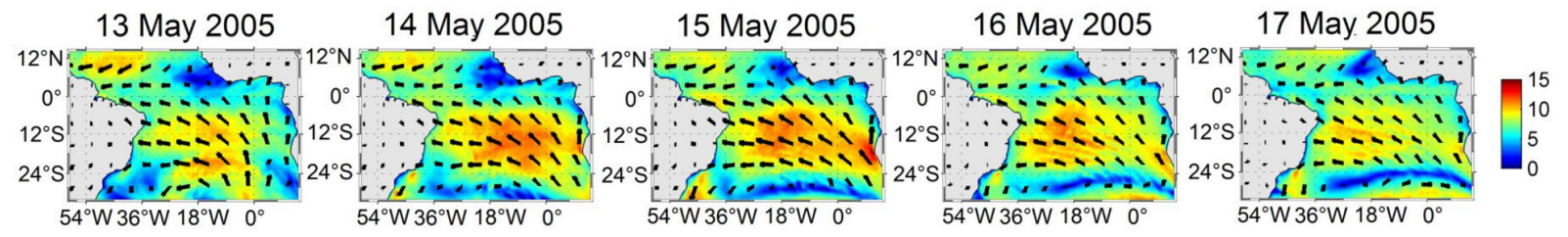

(b)
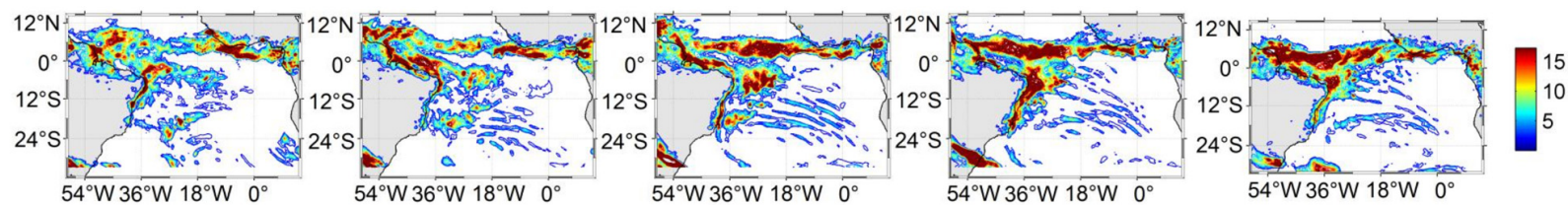

(c)
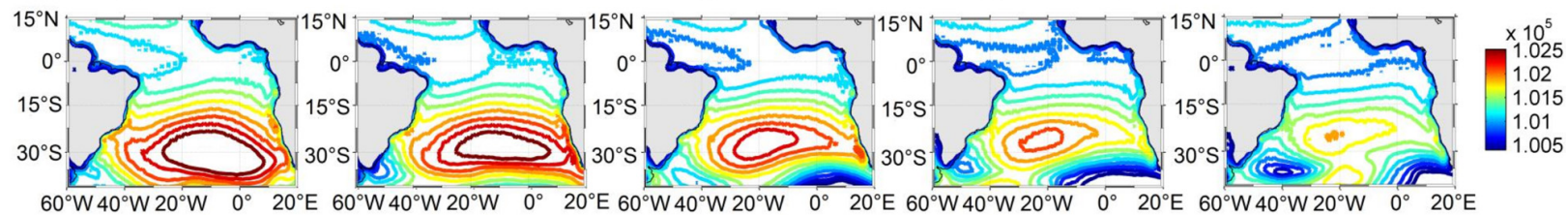

(d)
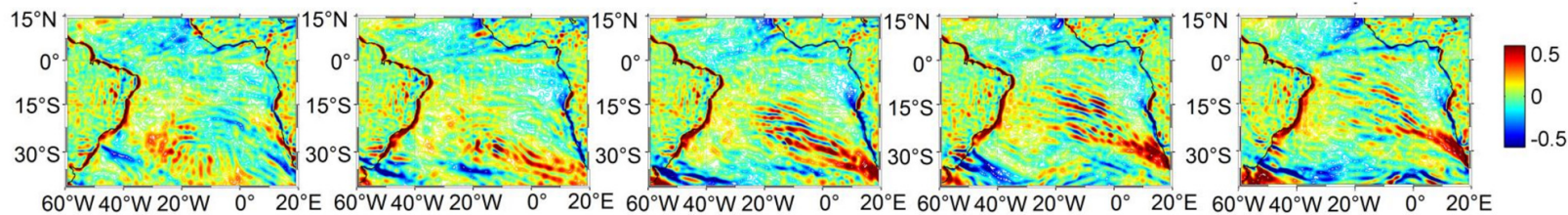

$60^{\circ} \mathrm{W} 40^{\circ} \mathrm{W} 20^{\circ} \mathrm{W} \quad 0^{\circ} 20^{\circ} \mathrm{E} \quad 60^{\circ} \mathrm{W} 40^{\circ} \mathrm{W} 20^{\circ} \mathrm{W} \quad 0^{\circ} \quad 20^{\circ} \mathrm{E} \quad 60^{\circ} \mathrm{W} 40^{\circ} \mathrm{W} 20^{\circ} \mathrm{W} \quad 0^{\circ} \quad 20^{\circ} \mathrm{E} 60^{\circ} \mathrm{W} 40^{\circ} \mathrm{W} 20^{\circ} \mathrm{W} \quad 0^{\circ} \quad 20^{\circ} \mathrm{E} \quad 60^{\circ} \mathrm{W} 40^{\circ} \mathrm{W} 20^{\circ} \mathrm{W} \quad 0^{\circ} \quad 20^{\circ} \mathrm{E}$

(e)
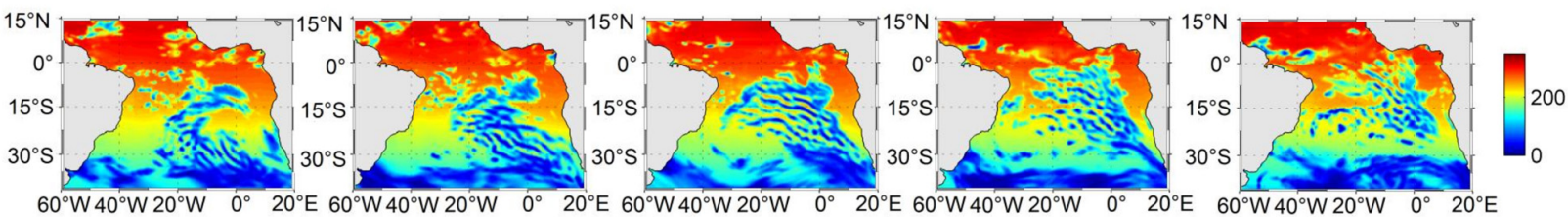

Figure 10. Daily average, from 13 to 17 May 2005 (left to right panels), of (a) wind magnitude (color field) $\left(\mathrm{m} \mathrm{s}^{-1}\right.$ ) superimposed with wind vectors from CFSR fields, (b) precipitation rate $\left(\mathrm{kg} \mathrm{m}^{-2} \mathrm{day}^{-1}\right.$ ) from CFSR fields, (b) surface pressure (hPa) from ERA-20C reanalysis, (c) wind speed curl $\left(\mathrm{m} \mathrm{s}^{-1}\right)$ computed from CFSR wind speed fields, and (d) downward shortwave radiation $\left(\mathrm{W} \mathrm{m}^{-2}\right)$ from CFSR fields.

regions caused by unusually early cooling in the ACT region at this time of the year.

\subsubsection{Generation of atmospheric gravity wave}

The precipitation fields during the mid-May event (Fig. 10b) also evidence a rainfall pattern typical of an atmospheric gravity wave train characterized by a horizontal wavelength $\sim 500 \mathrm{~km}$ and initiated by a front system (forming the northern boundary of a low-pressure system) that developed around $17^{\circ} \mathrm{S}$ on 14 May and traveled northeastward until 17 May. The rainfall train was associated with an oscillatory wind speed curl train alternating between positive and negative values (Fig. 10d) and an alternating downward shortwave radiation minimum (Fig. 10e) associated with wave clouds. Gravity waves are known to play an important role in transporting momentum and energy through long distances (Fritts, 1984). Here, they would be a way to carry momentum and energy from the South Atlantic to the Equator during the strong event.

\subsection{A decisive event for coastal monsoon onset}

The mid-May 2005 wind event was found to be involved in the early onset of the ACT development (Marin et al. 2009; Caniaux et al., 2011). The influence of the cold tongue on the WAM onset has been suggested by several authors (Okumura and Xie, 2004; Caniaux et al., 2011; Nguyen et al., 2011; Thorncroft et al., 2011). At the seasonal timescale, Caniaux et al. (2011) suggest that it comes from strong interactions between the SST cooling and wind pattern in the eastern equatorial Atlantic: the ACT serves to accelerate (decelerate) winds in the Northern (Southern) Hemisphere, contributing to the northward migration of humidity and convection and pushing precipitation to the continent. Thus, due to its impact on ACT development, the mid-May 2005 wind event is also linked to the onset of the WAM in 2005, which was the earliest over the 1982-2007 period in Caniaux et al. (2011). In this section we aim to better understand how this single wind event may have such an impact. For further information on the WAM, the reader can refer to Leduc-Leballeur et al. (2013) and Caniaux et al. (2011). 
In order to analyze the air-sea pattern in the northern Gulf of Guinea during May-June 2005, we show in Fig. 11 the wind magnitude, precipitation rate, and SST fields averaged from 10 to $6^{\circ} \mathrm{W}$. The wind strengthening appeared first south of the Equator on 12-16 May and then north of the Equator from 14-18 May. It was associated with strong rainfall extending southward up to $2^{\circ} \mathrm{N}$. Equatorial cooling occurred 4 days after the event and slowed down the overlying winds through feedback mechanisms. The winds north of the Equator then remained stronger than in the ACT region and strengthened again north of the Equator on 22-28 May together with a precipitation maximum that pushed northward (around $5^{\circ} \mathrm{N}$ ) after the event.

Thus, this mid-May event appears as the "decisive event" that triggered the abrupt transition between the two wind patterns in the northern Gulf of Guinea, when the wind north of the Equator became and remained stronger than south of the Equator. It occurred 15 days earlier than the average date (31 May) identified by Leduc-Leballeur et al. (2013) over the 2000-2009 period. According to these authors, the time of occurrence of this phenomenon should be related to the strength of anomalous moisture flux. They explain that in April-May the low atmospheric local circulation is present only during an equatorial SST cooling and surface wind strengthening north of the Equator, both generated by a southerly wind burst, before disappearing until the next wind burst. In June-July the low atmospheric local circulation is then always present and intensified by the wind bursts. Thus, the establishment of an abrupt seasonal transition event as observed in 2005, occurring much earlier than the reference date, catalyzed anomalously strong equatorial cooling caused by unusually strong southerly winds that allowed, through air-sea interaction mechanisms, deep atmospheric convection in the Gulf of Guinea to be triggered at a self-sustaining level.

\subsection{What made the mid-May 2005 event so special?}

To better understand what constitutes the particularity of the mid-May 2005 event, the atmospheric and oceanic conditions (SST, intraseasonal SST anomalies, intraseasonal shortwave radiation flux anomalies (hereafter RADSW), intraseasonal wind stress magnitude anomalies, intraseasonal z20 anomalies, and intraseasonal meridional SST gradient anomalies) averaged over the $10-6^{\circ} \mathrm{W}$ region and between $15^{\circ} \mathrm{S}$ and $5^{\circ} \mathrm{N}$ during April-May are analyzed over the 1998-2008 period (Fig. 12). The intraseasonal wind stress magnitude anomaly during the mid-May event appears to be one of the strongest over the whole 1998-2008 period (up to $0.13 \mathrm{~N} \mathrm{~m}^{-2}$ around $15^{\circ} \mathrm{S}$ and $0.05 \mathrm{~N} \mathrm{~m}^{-2}$ in the equatorial region). These strong wind conditions are usually found later in late boreal spring or summer, when the St. Helena anticyclone strengthens and shifts northward toward the warm hemisphere. The wind intensification in mid-May 2005 was associated with particularly weak RADSW from the South
Atlantic to the northern equatorial region, suggesting a cloud albedo effect during the event that tended to cool the mixed layer. We can notice that the April-May 2005 period was characterized by the lowest mean RADSW.

In addition, at the time of the event, the surface waters were already cooled by previous wind bursts (e.g., 20 April and 8 May). The SST response to the mid-May event occurred 4-6 days later, inducing the weakest equatorial SST values for the April-May season over the whole 1998-2008 period (SST drop of $\sim 3{ }^{\circ} \mathrm{C}$ inducing $\mathrm{SST}<24.8^{\circ} \mathrm{C}$ ). The cooling also caused an enhanced SST front around $1^{\circ} \mathrm{N}$, as shown in Fig. 12 (panel f), which was found to be the earliest and strongest over the 1998-2008 period. This meridional SST gradient was responsible for the wind surface intensification north of the Equator (Figs. 11a and 12d) through airsea interaction mechanisms as described by Leduc-Leballeur et al. (2011). Another SST gradient maximum is found at the end of May 1998 but it was not extended as far eastward as during the mid-May 2005 event (not shown).

When the wind burst occurred on 14 May 2005 , the $20^{\circ} \mathrm{C}$ isotherm depth in the area was anomalously shallow south of the Equator and slightly deeper at the Equator (Fig. 12e). The thermocline shoaling associated with the Kelvin wave appeared, in fact, a few days earlier, providing favorable subsurface conditions that made the SST response to previous wind bursts (20 April and 8 May) more effective. At the time of the mid-May event, the wave already reached more eastern areas, as shown in previous sections.

Thus, the particularity of the mid-May 2005 event mainly lies in the (i) anomalous atmospheric conditions related to strong St. Helena anticyclone perturbation, (ii) cooling initiated by the succession of previous wind bursts, and (iii) favorable subsurface local ocean conditions preconditioned by equatorial waves that shoaled the mixed layer. Another wind burst of comparable intensity occurred at the beginning of May 2000 (Fig. 12d) while the thermocline was shallow, causing SST cooling at the Equator (Fig. 12a and b). However, the wind strengthening was less sudden than during the mid-May 2005 event and the resulting cooling took place over a less broad region (not shown). In addition, the surface pressure drop in the ITCZ region was not as pronounced as during the mid-May 2005 event.

\section{Summary and discussion}

In this study, the impact of intraseasonal winds on SST in the far eastern tropical Atlantic during boreal spring 2005 and 2006 has been investigated from observations and numerical simulation. We first focus our study in the Cape Lopez region (CLR), east of $5^{\circ} \mathrm{E}$ and between the Equator and $7^{\circ} \mathrm{S}$, where the seasonal and interannual SST variability is poorly documented. There, the boreal spring (AMJ) season corresponds to a transitional period between high SST in boreal winter and low ST in boreal summer under the influence of 
(a) Wind speed - 2005

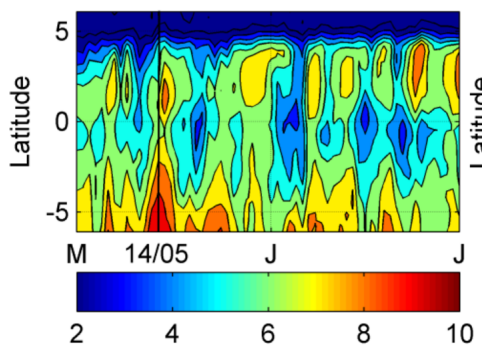

(b) Precip - 2005

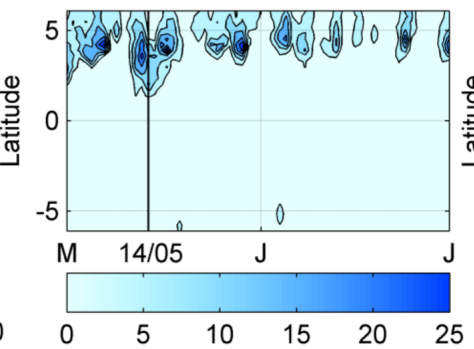

(c) Temp - 2005

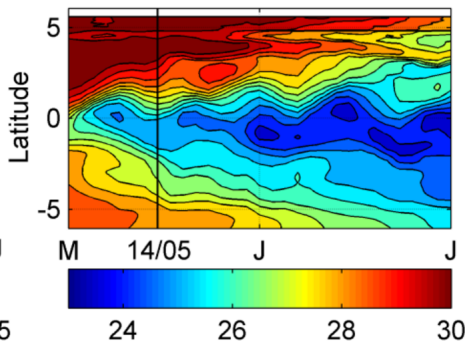

Figure 11. Time evolution, in May and June 2005 between $6^{\circ} \mathrm{S}$ and $6^{\circ} \mathrm{N}$ and averaged between 10 and $6^{\circ} \mathrm{W}$, of the (a) daily averaged wind magnitude $\left(\mathrm{m} \mathrm{s}^{-1}\right)$ from CFSR wind fields, (b) daily averaged precipitation rate $\left(\mathrm{kg} \mathrm{m}^{-2} \mathrm{day}^{-2}\right)$ from CFSR fields, and (c) 2-daily averaged SST $\left({ }^{\circ} \mathrm{C}\right)$ fields from the forced model.

(a)

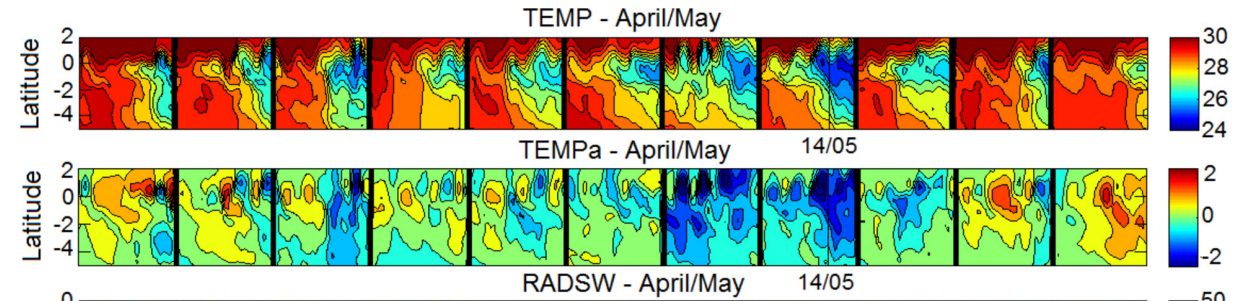

(c)

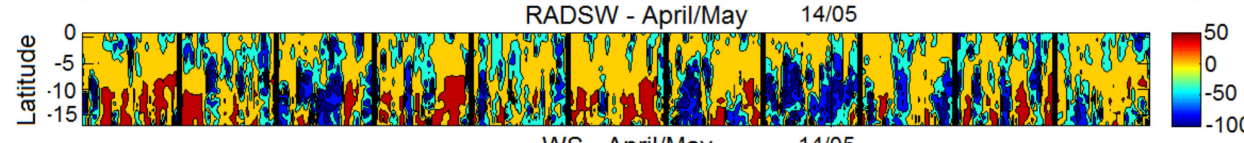

(d)

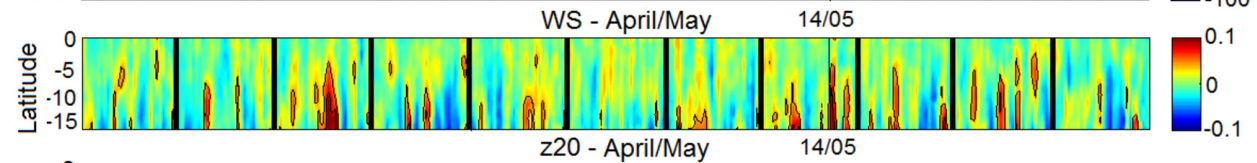

(e)

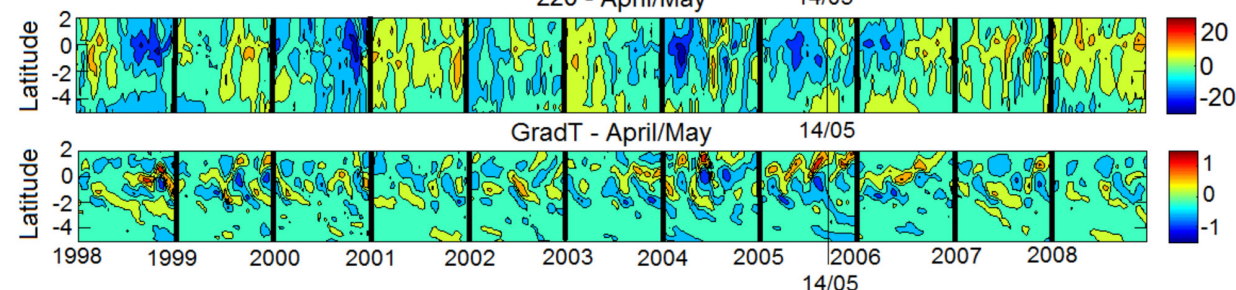

Figure 12. Time-latitude diagrams for April-May along the $1998-2008$ period of 2-day averages. From top to bottom: (a) SST ( $\left.{ }^{\circ} \mathrm{C}\right)$; (b) intraseasonal anomaly of SST $\left({ }^{\circ} \mathrm{C}\right)$; (c) intraseasonal anomaly of shortwave radiation surface flux (W m ${ }^{-2}$ ) from CFSR fields ; (d) intraseasonal anomaly of wind stress magnitude $\left(\mathrm{N} \mathrm{m}^{-2}\right)$ from CFSR fields; (e) intraseasonal anomaly of $20^{\circ} \mathrm{C}$ isotherm depth $(\mathrm{m})$ computed from the forced model SST; (f) intraseasonal anomaly of meridional SST gradient (every $0.5^{\circ}$ of latitude) from the forced model averaged over $10-6^{\circ} \mathrm{W}$. The thin vertical black line indicates the date of 14 May 2005. For details about the calculations of the anomalies, see Sect. 2.

local winds. Intensified cool SSTs are observed in the coastal upwelling area located around $6^{\circ} \mathrm{S}$ in the Congo mouth region, associated with mean alongshore wind conditions. The boreal spring season is in fact characterized by maximum winds amplitudes, the influence of which is made more effective by a shallow thermocline depth, itself strongly influenced by remote forcing. The seasonal cycle in the CLR is modulated by strong year-to-year variations, as observed in boreal spring 2005 when cold SST anomalies are associated with shallower-than-average thermocline depth and positive wind speed anomaly.

The intraseasonal wind bursts that occurred in boreal spring 2005 and 2006 generated cooling episodes, espe- cially around $3-4^{\circ} \mathrm{S}$, except for some of the strongest events when the cooling reached the more northern equatorial region during the mid-May and end May 2005 events. The intensity of the cold events resulted from basin preconditioning by remotely forced shoaling of the thermocline (via Kelvin wave), local mixing (induced by current vertical shear), and upwelling processes in response to strong southerly local winds. For one particular event on 26-28 May 2005, the net heat flux also tended to cool the surface water due to enhanced cloud cover that decreased the incoming solar radiation. In the CLR, stronger wind intensification and favorably preconditioned oceanic subsurface conditions in 2005 made the coupling between surface and subsurface ocean processes 
more efficient than in 2006, resulting in stronger cooling. It should be noted that the occurrence of intraseasonal wind intensification in the CLR is not specific to the boreal springsummer 2005 and 2006 and is observed every year over the 1998-2008 period of study (not shown). However, its impact on SST variability in the region is modulated depending of the strength of wind intensification and of the subsurface preconditioning. For example, the year 1998, known as a "warm year", is characterized by anomalously warm SST in boreal spring-summer in the CLR associated with anomalously weak winds and an anomalously deep thermocline.

The preconditioning of subsurface conditions in the area via Kelvin waves on the dates of the wind bursts depended on the atmospheric conditions in the western part of the basin a few weeks earlier. Previous studies (e.g., Picaut, 1983; Philander, 1990) suggest that the source of an equatorial Kelvin wave is mainly related to a sudden change in the zonal wind in the west. Analysis of atmospheric and oceanic conditions at an intraseasonal to daily scale in winter 2005 and 2006 showed that for both years, a Kelvin upwelling wave was initiated in the west, while easterly winds were strengthened from either side of the Equator just after the ITCZ to be at its southernmost location. This latter was observed 1 month earlier in 2006 (late February-early March) than in 2005 (late March-early April) and was associated with a negative wind stress curl anomaly. In winter 2005, the ITCZ was found south of the Equator after a very sudden southward shift and was followed by strong easterlies during $\sim 20$ days. In winter 2006, the ITCZ was found closer to the Equator less sharply and during a longer period, followed by weaker easterlies when compared to 2005 . These results obtained for the years 2005 and 2006 years do not imply that same atmospheric conditions would be observed for winter upwelling Kelvin waves of other years. The year 2005 was very particular and also exhibited anomalously cold SSTs in the South Atlantic and anomalously warm SSTs in the North Atlantic initiated in fall 2004, the signature of a meridional mode (Virmani and Weisberg, 2006; Foltz and McPhaden, 2006; Hormann and Brandt, 2009).

Upon impingement at the eastern boundary, the incoming equatorial Kelvin wave excites westward-propagating Rossby waves and poleward-propagating coastal Kelvin waves. In 2005, the Kelvin wave reached the coast around mid-May while southerly winds strengthened, allowing the reflected wave to be reinforced by the local wind. This resulted in westward propagation of negative z20 and SSH anomalies, which combined with enhanced westward surface currents provided favorable conditions for the westward extension of cold upwelled water from the eastern coast to near $20^{\circ} \mathrm{W}$ through advection and vertical mixing.

In the second part of the study, we especially focused on the mid-May 2005 event (13 to 16 May) that was characterized by strong southerly wind strengthening in the eastern tropical Atlantic Ocean. It was found to be responsible for the sudden and intense SST cooling in the Gulf of Guinea and the CLR and involved in the early onset of the ACT development in 2005 and therefore in the early onset of the WAM. The analysis of atmospheric and oceanic conditions in the Gulf of Guinea associated with this event allowed us to show that the mid-May event, controlled by the St. Helena anticyclone, can be identified as a "decisive event" that triggered the abrupt transition between two wind patterns in the northern Gulf of Guinea. Unusually strong southerly winds induced anomalously strong equatorial cooling, which in turn slowed down the overlying wind feedback mechanism and generated stronger than normal southerlies north of the Equator through the SST front around $1^{\circ} \mathrm{N}$. This triggered the deep atmospheric convection in the Gulf of Guinea at a self-sustaining level and the beginning of coastal precipitation. The time of occurrence of this phenomenon, 15 days earlier than the average date (31 May in Leduc-Leballeur et al., 2013), suggests that the mid-May 2005 event was associated with anomalously strong moisture flux. The description of atmospheric conditions over the 1998-2008 period has shown that the 2005 event was characterized by the strongest surface pressure gradient between the St. Helena high pressures and the low pressures under the ITCZ, inducing strong Hadley cell activity. No similar atmospheric pattern was observed during the whole 1998-2008 period. Another wind burst of comparable wind intensity occurred at the beginning of May 2000. This event also induced a cooling at the Equator but the surface pressure decrease in the ITCZ region was not as pronounced as during the mid-May 2005 event and the SST gradient around $1^{\circ} \mathrm{N}$ was weaker. In addition to coastal precipitation in the Gulf of Guinea and due to the early cooling in the ACT region, unusual rainfall conditions also occurred between the northeast coast of Brazil and $15^{\circ} \mathrm{W}$ within the SITCZ, which generally forms in early boreal summer.

Finally, this study highlights the importance of a strong southerly wind burst in the eastern tropical Atlantic during boreal spring season, which is a transitional period during which an anomalously strong energy input may tip the energy balance from an equilibrium state toward another one and thus impact the WAM system. The analysis of atmospheric and oceanic conditions during the mid-May 2005 wind event allows us to highlight the different processes through which the wind power provided by the wind burst is brought to the ocean:

i. direct effect of the wind on the SST in the eastern tropical Atlantic;

ii. changes in the trade winds in the western equatorial Atlantic exciting eastward-propagating equatorial Kelvin waves;

iii. energy transport via atmospheric gravity waves from the South Atlantic; and

iv. energy supply to Rossby waves. In addition to unusual atmospheric conditions in mid-May 2005, the ocean re- 
sponse intensity to this event was also enhanced by the subsurface conditions, made favorable by previous wind bursts either locally (e.g., in 6-8 May) or occurring a few weeks before in the west.

It is crucial to better describe the atmospheric and oceanic processes at play during such an extreme event, notably in order to reduce the well-known warm bias in the southeastern tropics in coupled models in both atmospheric and oceanic components (Zeng et al., 1996; Davey et al., 2002; Deser et al., 2006; Chang et al., 2007; Richter and Xie, 2008) as well as in forced ocean-only simulations (e.g., Large and Danabasoglu, 2006). This warm bias is well evidenced in our numerical simulation (Figs. 1 and 2) and our results clearly show that the cooling episodes were underestimated in the CLR, implying the need to investigate more in-depth the oceanic and atmospheric processes at play in this particular region. As the intraseasonal wind bursts are related to the fluctuations of the St. Helena anticyclone, their impact on SST variability in the eastern tropical Atlantic and regional climate suggests the need for better understanding the St. Helena anticyclone variability.

It is also important to note that the mid-May 2005 event occurred during an unusually active year. The year 2005 exhibited a pronounced meridional mode pattern with a strong SST gradient between the two hemispheres. Several authors (Foltz et al., 2006; Virmani and Weisberg, 2006; Marengo et al., 2008a, b; Zeng et al., 2008) studied this particular year, marked by anomalously warm SST in the tropical North Atlantic during March-July, the warmest from at least 150 years. This anomalous warming was associated with the most active and destructive hurricane season on record (Foltz et al., 2006; Virmani and Weisberg, 2006) and an extreme and rare drought in the Amazon Basin (Marengo et al., 2008a, b; Zeng et al. 2008; Erfanian et al., 2017). The primary causes of the anomalous warming in 2005 were found to be a weakening of the northeasterly trade winds and associated decrease in wind-induced latent heat loss as well as changes in shortwave radiation and horizontal oceanic heat advection. This 2005 temperature record is made even more remarkable given that, unlike the 1998 one, it occurred in the absence of any strong El Niño anomaly (Shein, 2006). Some studies (Goldenberg et al., 2001) attribute these SST increases to the Atlantic Multidecadal Oscillation (AMO), while others suggest that climate change may instead be playing the dominant role (Emanuel, 2005; Webster et al., 2005; Mann and Emanuel, 2006; Trenberth and Shea, 2006). Comparable anomalously warm tropical Atlantic SSTs have been observed in 2010 also associated with extreme drought in the Amazon. However, from time series of monthly anomalies constructed for the two basins (North and South Atlantic) by using OISST monthly mean data, Erfanian et al. (2017) show that the warmer-than-usual SSTs in the North Atlantic in 2010 were not associated with colder-than-usual SST in the South Atlantic in contrast to 2005 (their Fig. S4e).

While the warming in the northern tropical Atlantic during 2005 has been investigated by several authors, the cooling in the South Atlantic has received less attention. This study highlights the need to further document and monitor the South Atlantic region and the St. Helena anticyclone through additional high-resolution analysis and observations.

Data availability. The TMI SST data that support the findings of this study are openly available at http: //www.remss.com/missions/tmi (Wentz et al., 2015). The SSH data are openly available at https://www.aviso.altimetry.fr/en/data/ products/sea-surface-height-products/global/msla-h.html (AVISO, 2017) and need an authentication for access. The ECMWF data are openly available at https://doi.org/10.5065/D6VQ30QG (European Centre for Medium-Range Weather Forecasts, 2014) upon an authentication.

Author contributions. GH performed the analytic calculations and numerical simulations and analyzed the data. BB provided critical feedback and helped to shape the research, analysis, and paper. GH and $\mathrm{BB}$ discussed the results and $\mathrm{GH}$ wrote the paper in consultation with BB.

Competing interests. The authors declare that they have no conflict of interest.

Acknowledgements. The research leading to these results received funding from the EU FP7/2007-2013 under grant agreement no. 603521, PREFACE, and the EU Horizon 2020 program under grant agreement no. 2014-633211, AtlantOS. These projects are gratefully acknowledged. We thank Gildas Cambon (IRD/LOPS) for his help and participation in the implementation of ROMS simulations and Frédéric Marin (IRD/LEGOS) for his helpful comments. We would also like to thank NASA, CNES, and ECMWF for freely providing the data and products used in this study.

Edited by: Mario Hoppema

Reviewed by: three anonymous referees

\section{References}

Adamec, D. and O'Brien, J. J.: The seasonal upwelling in the Gulf of Guinea due to remote forcing, J. Phys. Oceanogr., 8, 10501060, 1978.

AVISO: Mean Sea Level: Aviso, Aviso Altimetry, available at: https://www.aviso.altimetry.fr/en/data/products/ sea-surface-height-products/global/msla-h.html, last access: July 2017. 
Battisti, D. S.: Dynamics and thermodynamics of a warming event in a coupled tropical atmosphere ocean model, J. Atmos. Sci. 45, 2889-2919, 1988.

Busalacchi, A. and Picaut, J.: Seasonal variability from a model of the tropical Atlantic Ocean, J. Phys Oceanogr., 13, 1564-1588, 1983.

Bourlès, B., Brandt, P., Caniaux, G., Dengler, M., Gouriou, Y., Key, E., Lumpkin, R., Marin, F., Molinari, R. L., and Schmid, C.: African Monsoon Multidisciplinary Analysis (AMMA): Special measurements in the Tropical Atlantic, CLIVAR Exchange Letters, 41, International CLIVAR Project Office, National Oceanography Centre, Southampton, UK, 7-9, 2007.

Brandt, P., Funk, A., Hormann, V., Dengler, M., Greatbatch, R. J., and Toole, J. M.: Interannual atmospheric variability forced by the deep equatorial Atlantic Ocean, Nature, 473, 497-500, https://doi.org/10.1038/nature10013, 2011.

Caniaux, G., Giordani, H., Redelsperger, J.-L., Guichard, F., Key, E., and Wade, M.: Coupling between the Atlantic cold tongue and the West African monsoon in boreal spring and summer, J. Geophys. Res., 116, C04003, https://doi.org/10.1029/2010JC006570, 2011.

Carton, J. A. and Giese, B. S.: A reanalysis of ocean climate using simple ocean data assimilation (SODA), Mon. Weather Rev., 136, 2999-3017, https://doi.org/10.1175/2007MWR1978.1, 2008.

Carton, J. A., Chepurin, G., Cao, X., and Giese, B. S.: A simple ocean data assimilation analysis of the global upper ocean 1950-1995, part 1: Methodology, J. Phys. Oceanogr., 30, 294-309, https://doi.org/10.1175/15200485(2000)030<0294:ASODAA >2.0.CO;2, 2000a.

Carton, J. A., Chepurin, G., and Cao, X.: A simple ocean data assimilation analysis of the global upper ocean 1950-1995, part 2: Results, J. Phys. Oceanogr., 30, 311-326, https://doi.org/10.1175/15200485(2000)030<0311:ASODAA >2.0.CO;2, $2000 \mathrm{~b}$.

Chang, C.-Y., Carton, J. A., Grodsky, S. A., and Nigam, S.: Seasonal climate of the tropical Atlantic sector in the NCAR Community Climate System Model 3: Error structure and probable causes of errors, J. Climate, 20, 1053-1070, 2007.

Chelton, D. B., deSzoeke, R. A., Schlax, M. G., Naggar, K. E., and Siwertz, N.: Geographical variability of the first-baroclinic Rossby radius of deformation, J. Phys. Oceanogr., 28, 433-460, 1998.

Colin, C.: Sur la variabilité dans le Golfe de Guinée: Nouvelles considérations sur les mécanismes d'upwelling, $\mathrm{PhD}$ thesis, Mus. Natl. d'Hist. Nat., Paris, 1989.

Dai, A. and Trenberth, K. E.: Estimates of freshwater discharge from continents: Latitudinal and seasonal variations, J. Hydrometeorol., 3, 660-687, 2002.

Davey, M., Huddleston, M., Sperber, K. R., Braconnot, P., Bryan, F., Chen, D., Colman, R., Cooper, C., Cubasch, U., Delecluse, P., DeWitt, D., Fairhead, L., Flato, G., Gordon, C., Hogan, T., Ji, M., Kimoto, M., Kitoh, A., Knutson, T. R., Latif, M., Le Treut, H., Li, T., Manabe, S., Mechoso, C. R., Meehl, G. A., Power, S. B., Roeckner, E., Terray, L., Vintzileos, A., Voss, R., Wang, B., Washington, W. M., Yoshikawa, I., Yu, J.-Y., Yukimoto, S., and Zebiak, S. E.: STOIC: A study of coupled model climatology and variability in tropical ocean regions, Clim. Dynam., 18, 403-420, 2002.
Debreu, L., Marchesiello, P., Penven, P., and Cambon, G.: Two-way nesting in split-explicit ocean models: algorithms, implementation and validation, Ocean Model., 49-50, 1-21, 2012.

de Coëtlogon, G., Janicot, S., and Lazar, A.: Intraseasonal variability of the ocean-atmosphere coupling in the Gulf of Guinea during boreal spring and summer, Q. J. Roy. Meteor. Soc., 136, 426441, https://doi.org/10.1002/qj.554, 2010.

Denamiel, C., Budgell, W. P., and Toumi, R.: The Congo River plume: Impact of the forcing on the far-field and near-field dynamics, J. Geophys. Res.-Oceans, 118, 964-989, https://doi.org/10.1002/jgrc.20062, 2013.

Deser, C., Capotondi, A., Saravanan, R., and Phillips, A.: Tropical Pacific and Atlantic climate variability in CCSM3, J. Climate, 19, 2451-2481, 2006.

Djakouré, S., Penven, P., Bourlès, B., Veitch, J., and Koné, V.: Coastally trapped eddies in the north of the Gulf of Guinea, J. Geophys. Res.-Oceans, 119, 6805-6819, https://doi.org/10.1002/2014JC010243, 2014.

Emanuel, K.: Increasing destructiveness of tropical cyclones over the past 30 years, Nature, 436, 686-688, 2005.

Erfanian, A., Wang, G., and Fomenko, L.: Unprecedented drought over tropical South America in 2016: significantly under-predicted by tropical SST, Sci. Rep., 7, 5811, https://doi.org/10.1038/s41598-017_05373-2, 2017.

European Centre for Medium-Range Weather Forecasts: ERA-20C Project (ECMWF Atmospheric Reanalysis of the 20th Century), Research Data Archive at the National Center for Atmospheric Research, Computational and Information Systems Laboratory, Boulder, CO, https://doi.org/10.5065/D6VQ30QG, 2014.

Foltz, G. R., Grodsky, S. A., Carton, J. A., and McPhaden, M. J.: Seasonal mixed layer heat budget of the tropical Atlantic Ocean, J. Geophys. Res., 108, 3146, https://doi.org/10.1029/2002JC001584, 2003.

Foltz, G. R. and McPhaden, M. J.: Unusually warm sea surface temperatures in the tropical North Atlantic during 2005, Geophys. Res. Lett., 33, L19703, https://doi.org/10.1029/2006GL027394, 2006.

Fritts, D. C.: Wave saturation in the middle atmosphere: A review of theory and observations, Rev. Geophys., 22, 275-308, 1984.

Gentemann, C. L., Wentz, F. J., Brewer, M., Hilburn, K., and Smith, D.: Passive Microwave Remote Sensing of the Ocean: an Overview, Oceanography from Space, Revisited, edited by: Barale, V., Gower, J., and Alberotanza, L., 13-33, Springer, Heidelberg, 2010.

Giese, B. J. and Harrison, D. E.: Aspects of the Kelvin wave response to episodic wind forcing, J. Geophys. Res., 95, 7289$7312,1990$.

Giordani, H., Caniaux, G., and Voldoire, A.: Intraseasonal mixedlayer heat budget in the equatorial Atlantic during the cold tongue development in 2006, J. Geophys. Res.-Oceans, 118, 650-671, https://doi.org/10.1029/2012JC008280, 2013.

Goldenberg, S. B., Landsea, C. W., Mestas-Nuñez, A. M., and Gray, W. M.: The Recent Increase in Atlantic Hurricane Activity: Causes and Implications, Science, 293, 474-479, https://doi.org/10.1126/science.1060040, 2001.

Grodsky, S. A. and Carton, J. A.: The Intertropical Convergence Zone in the South Atlantic and the Equatorial Cold Tongue, J. Climate, 16, 723-733, 2003. 
Haidvogel, D. B. and Beckmann, A.: Numerical Ocean Circulation Modeling, Imperial College Press, London, 320 pp., 1999.

Herbert, G., Bourlès, B., Penven, P., and Grelet, J.: New insights on the upper layer circulation north of the Gulf of Guinea, J. Geophys. Res.-Oceans, 121, 6793-6815, https://doi.org/10.1002/2016JC011959, 2016.

Hormann, V. and Brandt, P.: Upper equatorial Atlantic variability during 2002 and 2005 associated with equatorial Kelvin waves, J. Geophys. Res., 114, C03007, https://doi.org/10.1029/2008JC005101, 2009.

Illig, S., Dewitte, B., Ayoub, N., du Penhoat, Y., Reverdin, G., Mey, P. D., Bonjean, F., and Lagerloef, G. S. E.: Interannual long equatorial waves in the tropical Atlantic from a high-resolution ocean general circulation model experiment in 1981-2000, J. Geophys. Res.-Oceans, 109, C02022, https://doi.org/10.1029/2003JC001771, 2004.

Jouanno, J., Marin, F., duPenhoat, Y., Sheinbaum, J., and Molines, J. M.: Seasonal heat balance in the upper $100 \mathrm{~m}$ of the Equatorial Atlantic Ocean, J. Geophys. Res.-Oceans, 116, C09003, https://doi.org/10.1029/2010JC006912, 2011.

Jouanno, J., Marin, F., duPenhoat, Y., and Molines, J. M.: Intraseasonal Modulation of the Surface Cooling in the Gulf of Guinea, J. Phys. Oceanogr., 43, 382-401, https://doi.org/10.1175/JPO-D12-053.1, 2013.

Krishnamurti, T. N., Pasch, R. J., and Ardanuy, P.: Prediction of African waves and specification of squall lines, Tellus, 32, 215$231,1980$.

Large, W. G. and Danabasoglu, G.: Attribution and impacts of upper-ocean biases in CCSM3, J. Climate, 19, 2325-2346, 2006.

Leduc-Leballeur, M., Eymard, L., and de Coëtlogon, G.: Observation of the marine atmospheric boundary layer in the Gulf of Guinea during the 2006 boreal spring, Q. J. Roy. Meteorol. Soc., 137, 992-1003, 2011.

Leduc-Leballeur, M., de Coëtlogon, G., and Eymard, L.: Air - sea interaction in the Gulf of Guinea at intraseasonal time-scales: Wind bursts and coastal precipitation in boreal spring, Q. J. Roy. Meteorol. Soc., 139, 387-400, https://doi.org/10.1002/qj.1981, 2013.

Lübbecke, J. F., Burls, N. J., Reason, C. J. C., and McPhaden, M. J.: Variability in the South Atlantic Anticyclone and the Atlantic Nino Mode, J. Climate, 27, https://doi.org/10.1175/JCLI-D-14$00202.1,2014$.

Mann, M. E. and Emanuel, K. A.: Atlantic hurricane trends linked to climate change, Eos, Trans. Am. Geophys. Union, 87, 233244, 2006.

Marengo, J. A., Nobre, C. A., Tomasella, J., Oyama, M. D., De Oliveira, G. S., De Oliveira, R., Camargo, H., Alves, L. M., and Brown, I. F.: The drought of Amazonia in 2005, J. Climate, 21, 495-516, 2008a.

Marengo, J. A., Nobre, C. A., Tomasella, J., Cardoso, M. F., and Oyama, M. D.: Hydro-climatic and ecological behaviour of the drought of amazonia in 2005, Philosophical transactions of the Royal society of London, Biol. Sci., 21, 1-6, 2008 b.

Marin, F., Caniaux, G., Bourlès, B., Giordani, H., Gouriou, Y., and Key, E.: Why were sea surface temperatures so different in the Eastern Equatorial Atlantic in June 2005 and 2006, J. Phys. Oceanogr., 39, 1416-1431, https://doi.org/10.1175/2008JPO4030.1, 2009.
Materia, S., Gualdi, S., Navarra, A., and Terray, L.: The effect of Congo River freshwater discharge on Eastern Equatorial Atlantic climate variability, Clim. Dynam., 39, 2109-2125, https://doi.org/10.1007/s00382-012-1514-x, 2012.

McCreary, J.: Eastern tropical ocean response to changing wind systems with application to El Nino, J. Phys. Oceanogr., 6, 632-645, 1976.

McCreary, J., Picaut, J., and Moore, D.: Effects of the remote annual forcing in the eastern tropical Atlantic Ocean, J. Mar. Res., 42, 45-81, 1984.

Merle, J., Guillerm, J. M., and Pianet, R.: Conditions hydrologiques saisonniéres de la marge continentale du Gabon et du Congo (de $1^{\circ} \mathrm{N}$ a $6^{\circ} \mathrm{S}$ ), étude descriptive, Centre O.R.S.T.O.M, Doc., sci., Pointe-Noire, 27, 1-20, 1972.

Merle, J., Fieux, M., and Hisard, P.: Annual signal and interannual anomalies of sea surface temperature in the eastern equatorial Atlantic Ocean, Deep Sea Res., 26, 77-101, 1980.

Mitchell, T. P. and Wallace, J. M.: The annual cycle in equatorial convection and sea surface temperature, J. Climate, 5, 1140 1156, 1992.

Moore, D. W.: Planetary-gravity waves in an equatorial ocean, $\mathrm{PhD}$ thesis, Harvard University, 201 pp., 1968.

Moore, D. W. and Philander, S. G. H.: Modeling of the tropical ocean circulation, The Sea, Vol. 6, Wiley Interscience, New York, NY, 316-361, 1977.

Moore, D. W., Hisard, P., McCreary, J. P., Merle, J., O’Brien, J. J., Picaut, J., Verstraete, J. M., and Wunsch, C.: Equatorial adjustment in the eastern Atlantic, Geophys. Res. Lett., 5, 637-640, 1978.

Nguyen, H., Thorncroft, C. D., and Zhang, C.: Guinean coastal rainfall of the West African Monsoon, Q. J. Roy. Meteorol. Soc., 137, 1828-1840, https://doi.org/10.1002/qj.867, 2011.

Nicholson, S. E. and Dezfuli, A. K.: The relationship of rainfall variability in western equatorial Africa to the tropical oceans and atmospheric circulation, Part I: The boreal spring, J. Climate, 26, 45-65, 2013.

Nobre, P. and Shukla, J.: Variations of sea surface temperature, wind stress, and rainfall over the tropical Atlantic and South America, J. Climate, 9, 2464-2479, 1996.

Okumura, Y. and Xie, S. P.: Interaction of the Atlantic equatorial cold tongue and the African monsoon, J. Climate, 17, 35893602, 2004.

Okumura, Y. and Xie, S. P.: Some overlooked features of tropical Atlantic climate leading to a new Niño-like phenomenon, J. Climate, 19, 5859-5874, https://doi.org/10.1175/JCLI3928.1, 2006.

Ostrowski, M., Da Silva, J. C. B., and Bazik-Sangolay, B.: The response of sound scatterers to El-Niño and La Niña-like oceanographic regimes in the southeastern Atlantic, ICES J. Mar. Sci., 66, 1063-1072, https://doi.org/10.1093/icesjms/fsp102, 2009.

Penven, P., Marchesiello, P., Debreu, L., and Lefevre, J.: Software tools for pre- and post-processing of oceanic regional simulations, Environ. Model. Softw., 23, 660-662, 2008.

Peter, A.-C., Le Hénaff, M., du Penhoat, Y., Menkès, C., Marin, F., Vialard, J., Caniaux, G., and Lazar, A.: A model study of the seasonal mixed layer heat budget in the equatorial Atlantic, J. Geophys. Res., 111, C06014, https://doi.org/10.1029/2005JC003157, 2006. 
Philander, S. and Pacanowski, R.: A model of the seasonal cycle in the Tropical Atlantic Ocean, J. Geophys. Res., 91, 14192-14206, 1986.

Philander, S. G.: El Nino, La Nina and the Southern Oscillation, Academic Press, 293 pp., 1990.

Picaut, J.: Propagation of the seasonal upwelling in the eastern equatorial Atlantic, J. Phys. Oceanogr., 13, 18-37, https://doi.org/10.1175/15200485(1983)013<0018:POTSUI>2.0.CO;2, 1983.

Picaut, J.: On the dynamics of the thermal variations in the Gulf of Guinea, Oceanogr. Trop., 19, 127-153, 1984.

Piton, B.: Les courants sur le plateau continental devant PointeNoire (Congo), Documents scientifiques, ORSTOM, Brest, no. 47, 37 pp., 1988.

Polo, I., Lazar, A., Rodriguez-Fonseca, B., and Arnault, S.: Oceanic Kelvin waves and tropical Atlantic intraseasonal variability: 1 . Kelvin wave characterization, J. Geophys. Res., 113, C07009, https://doi.org/10.1029/2007JC004495, 2008.

Redelsperger, J. L., Diedhiou, A., Flamant, C., Janicot, S., Lafore, J. P., Lebel, T., Polcher, J., Bourlés, B., Caniaux, C., De Rosnay, P., Desbois, M., Eymard, L., Fontaine, B., Geneau, I., Ginoux, K., Hoepffner, M., Kane, C. C. S., Law, K., Mari, C., Marticoréna, B., Mougin, E., Pelon, J., Peugeot, C., Protat, A., Roux, F., Sultan, B., and Van den Akker, E.: AMMA: Une étude multidisciplinaire de la mousson Ouest-Africaine, Meteorologie, 54, 22-32, https://doi.org/10.4267/2042/20098, 2006

Richter, I. and Xie, S.-P.: On the origin of equatorial Atlantic biases in coupled general circulation models, Clim. Dynam., 1, 587598, https://doi.org/10.1007/s00382-008-0364-z, 2008.

Rouault, M., Servain, J., Reason, C. J. R., Bourlès, B., Rouault, M. J., and Fauchereau, N.: Extension of PIRATA in the tropical south-east Atlantic: An initial one-year experiment, Afr. J. Mar. Sci., 31, 63-71, https://doi.org/10.2989/AJMS.2009.31.1.5.776, 2009.

Saha, S., Moorthi, S., Pan, H.-L., Wu, W., Wang, J., Nadiga, S., Tripp, P., Kistler, R., Woollen, J., Behringer, D., Liu, H., Stokes, D., Grumbine, R., Gayno, G., Wang, J., Hou, Y. T., Chuang, H.Y., Juang, H.-M. H., Sela, J., Iredell, M., Treadon, R., Kleist, D., Van Delst, P., Keyser, D., Derber, J., Ek, M., Meng, J., Wei, H., Yang, R., Lord, S., Van Den Dool, H., Kumar, A., Wang, W., Long, C., Chelliah, M., Xue, Y., Huang, B., Schemm, J.-K., Ebisuzaki, W., Lin, R., Xie, P., Chen, M., Zhou, S., Higgins, W., Zou, C.-Z. Z., Liu, Q., Chen, Y., Han, Y., Cucurull, L., Reynolds, R. W., Rutledge, G., and Goldberg, M.: The NCEP climate forecast system reanalysis, Am. Meteor. Soc., 91, 1015-1057, 2010.

Schouten, M. W., Matano, R. P., and Strub, T. P.: A description of the seasonal cycle of the equatorial Atlantic from altimeter data, Deep-Sea Res., 52, 477-493, https://doi.org/10.1016/j.dsr.2004.10.007, 2005.

Servain, J., Picaut, J., and Merle, J.: Evidence of remote forcing in the equatorial Atlantic Ocean, J. Phys. Oceanogr., 12, 457-463, 1982 .
Shein, K. A.: State of the climate in 2005, B. Am. Meteor. Soc., 87, s1-s102, https://doi.org/10.1175/BAMS-87-6-shein, 2006.

Shchepetkin, A. and McWilliams, J. C.: The Regional Oceanic Modeling System (ROMS): A split-explicit, free-surface, topography-following-coordinate ocean model, Ocean Model. 9, 347-404, 2005.

Thorncroft, C. D., Nguyen, H., Zhang, C., and Peyrillé, P.: Annual cycle of the West African monsoon: regional circulations and associated water vapour transport, Q. J. Roy. Meteorol. Soc., 137, 129-147, https://doi.org/10.1002/qj.728, 2011.

Trenberth, K. E. and Shea, D. J.: Atlantic hurricanes and natural variability in 2005, Geophys. Res. Lett., 33, L12704, https://doi.org/10.1029/2006GL026894, 2006.

Virmani, J. I. and Weisberg, R. H.: The 2005 hurricane season: An echo of the past or a harbinger of the future?, Geophys. Res. Lett., 33, L05707, https://doi.org/10.1029/2005GL025517, 2006.

Wade, M., Caniaux, G., and du Penhoat, Y.: Variability of the mixed layer heat budget in the eastern equatorial Atlantic during 2005-2007 as inferred using Argo floats, J. Geophys. Res., 116, C08006, https://doi.org/10.1029/2010JC006683, 2011.

Waliser, D. E. and Gautier, C.: A satellite-derived climatology of the ITCZ, J. Climate, 6, 2162-2174, 1993.

Wauthy, B.: Introduction à la climatologie du Golfe de Guinée, Oceanogr. Trop., 18, 103-138, 1983.

Webster, P. J., Holland, G. J., Curry, A., and Chang, H. R.: Changes in tropical cyclone number, duration, and intensity, in warming environment, Science, 309, 1844-1846, 2005.

Wentz, F. J. and Meissner, T.: Algorithm Theoretical Basis Document (ATBD), version 2, AMSR-E Ocean Algorithm, Remote Sensing Systems Tech. Rep., RSS 121599A-1, 55 pp., 2000.

Wentz, F. J., Gentemann, C., and Hilburn, K. A.: Remote Sensing Systems TRMM TMI - 3-days data. Environmental Suite on 0.25 deg grid, Version 7.1, subset: Gulf of Guinea. Remote Sensing Systems, Santa Rosa, CA. Available online at http://www.remss com/missions/tmi (last access: June 2016), 2015.

White, R. H. and Toumi, R.: River Flow and Ocean Temperatures: The Congo River, J. Geophys. Res.-Oceans, 119, 25016-2517, https://doi.org/10.1002/2014JC009836, 2014.

Yu, L., Jin, X., and Weller, R. A.: Role of net surface heat flux in seasonal variations of sea surface temperature in the tropical Atlantic ocean, J. Climate, 19, 6153-6169, 2006.

Zebiak, S.: Air-sea interaction in the equatorial Atlantic region, J. Climate, 6, 1567-1586, https://doi.org/10.1175/15200442(1993)006<1567:AIITEA>2.0.CO;2, 1993.

Zeng, N., Dickinson, R. E., and Zeng, X.: Climatic impact of Amazon deforestation-A mechanistic model study, J. Climate, 9, 859883, 1996.

Zeng, N., Dickinson, R. E., and Zeng, X.: Causes and impacts of the 2005 Amazon drought, Environ. Res. Lett., 3, 014002, https://doi.org/10.1088/1748-9326/3/1/014002, 2008. 